\title{
Smartphone-Based Interventions to Reduce Sedentary Behavior and Promote Physical Activity Using Integrated Dynamic Models: Systematic Review
}

Reza Daryabeygi-Khotbehsara ${ }^{1}$, MSc; Sheikh Mohammed Shariful Islam ${ }^{1}$, MBBS, MPH, FESC, PhD; David Dunstan ${ }^{2,3}$, $\mathrm{PhD}$; Jenna McVicar ${ }^{1}, \mathrm{MSc}$; Mohamed Abdelrazek ${ }^{4}, \mathrm{PhD}$; Ralph Maddison ${ }^{1}, \mathrm{PhD}$

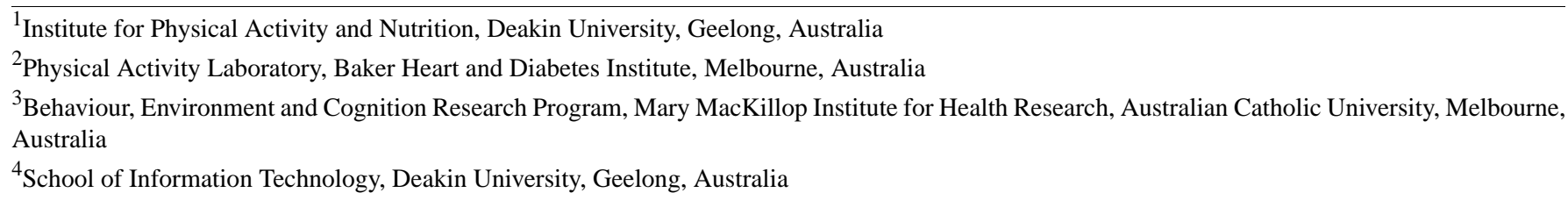

Corresponding Author:

Reza Daryabeygi-Khotbehsara, MSc

Institute for Physical Activity and Nutrition

Deakin University

75 Pigdons Road, Waurn Ponds Victoria

Geelong, 3216

Australia

Phone: 61392445936

Email: reza.d@deakin.edu.au

\section{Abstract}

Background: Traditional psychological theories are inadequate to fully leverage the potential of smartphones and improve the effectiveness of physical activity (PA) and sedentary behavior (SB) change interventions. Future interventions need to consider dynamic models taken from other disciplines, such as engineering (eg, control systems). The extent to which such dynamic models have been incorporated in the development of interventions for PA and SB remains unclear.

Objective: This review aims to quantify the number of studies that have used dynamic models to develop smartphone-based interventions to promote PA and reduce $\mathrm{SB}$, describe their features, and evaluate their effectiveness where possible.

Methods: Databases including PubMed, PsycINFO, IEEE Xplore, Cochrane, and Scopus were searched from inception to May 15, 2019, using terms related to mobile health, dynamic models, SB, and PA. The included studies involved the following: PA or SB interventions involving human adults; either developed or evaluated integrated psychological theory with dynamic theories; used smartphones for the intervention delivery; the interventions were adaptive or just-in-time adaptive; included randomized controlled trials (RCTs), pilot RCTs, quasi-experimental, and pre-post study designs; and were published from 2000 onward. Outcomes included general characteristics, dynamic models, theory or construct integration, and measured SB and PA behaviors. Data were synthesized narratively. There was limited scope for meta-analysis because of the variability in the study results.

Results: A total of 1087 publications were screened, with 11 publications describing 8 studies included in the review. All studies targeted PA; 4 also included SB. Social cognitive theory was the major psychological theory upon which the studies were based. Behavioral intervention technology, control systems, computational agent model, exploit-explore strategy, behavioral analytic algorithm, and dynamic decision network were the dynamic models used in the included studies. The effectiveness of quasi-experimental studies involved reduced SB ( 1 study; $P=.08)$, increased light PA ( 1 study; $P=.002)$, walking steps $(2$ studies; $P=.06$ and $P<.001$ ), walking time ( 1 study; $P=.02$ ), moderate-to-vigorous $P A$ ( 2 studies; $P=.08$ and $P=.81)$, and nonwalking exercise time ( 1 study; $P=.31$ ). RCT studies showed increased walking steps ( 1 study; $P=.003$ ) and walking time ( $1 \mathrm{study} ; P=.06$ ). To measure activity, 5 studies used built-in smartphone sensors (ie, accelerometers), 3 of which used the phone's GPS, and 3 studies used wearable activity trackers.

Conclusions: To our knowledge, this is the first systematic review to report on smartphone-based studies to reduce SB and promote PA with a focus on integrated dynamic models. These findings highlight the scarcity of dynamic model-based smartphone 
studies to reduce SB or promote PA. The limited number of studies that incorporate these models shows promising findings. Future research is required to assess the effectiveness of dynamic models in promoting PA and reducing SB.

Trial Registration: International Prospective Register of Systematic Reviews (PROSPERO) CRD42020139350; https://www.crd.york.ac.uk/PROSPERO/display_record.php?RecordID=139350.

(J Med Internet Res 2021;23(9):e26315) doi: 10.2196/26315

\section{KEYWORDS}

smartphone; mobile phone; physical activity; sedentary behavior; computational models; control systems; systematic review

\section{Introduction}

In the past decade, there has been a widespread proliferation in the use of digital technologies to deliver behavior change interventions for health [1]. Given their ubiquity, smartphones, in particular, have been used to improve a wide range of health-related behaviors, including physical activity (PA) and sedentary behavior (SB) [2,3]. Smartphones offer a host of relevant functions, including computational capabilities, built-in sensors (eg, accelerometers and GPS), and internet connectivity, enabling users to run software apps and connect with third-party sensors. Collectively, these features offer the potential for delivering real-time, context-aware, and interactive health care interventions [4].

Theory-based lifestyle interventions have been shown to be more effective than nontheoretical approaches [5]. Thus, to better leverage the potential of mobile technologies for health behavior interventions (mobile health [mHealth]), appropriate behavior change theories and models are needed. Such theories and models need to guide the design and development of complex smartphone interventions that can adapt rapidly in response to various inputs [4]. To date, many smartphone-based interventions to promote $\mathrm{PA}$ and reduce $\mathrm{SB}$ have relied predominantly on psychological theory, including social cognitive theory (SCT) and self-efficacy theory [2,6]. In a seminal paper, Riley et al [4] argued that current behavioral theories do not meet the need for a more dynamic and interactive nature of digital behavior change interventions, such as just-in-time adaptive interventions. These just-in-time adaptive interventions are complex interventions that adapt throughout time to an individual's time-varying context (where) and status (when) to meet an individual's changing needs for support [7-9]. Riley et al [4] argued that existing psychological theories are relatively static and linear and lack sufficient within-subject dynamic regulatory processes. Furthermore, current psychological theories have been used to tailor interventions based on preintervention data rather than deliver adaptive interventions.

To transform current theories into dynamic frameworks and fully maximize the potential of smartphone technologies, Riley et al [4] highlighted the need to incorporate theories from other disciplines (eg, computer science and engineering) for the future development of adaptive and dynamic digital behavior change interventions. One such theory is the control systems theory-derived from the control theory or cybernetics - which is a general concept for the understanding of regulatory processes [10] and has various applications in engineering, mathematics, medicine, and economics, among others. Control systems engineering explores how to influence and regulate a dynamic system (eg, time-varying adaptive PA intervention) $[11,12]$. Applying these dynamic models to health behaviors offers the potential to better predict behavior and provide greater insight into real-time changes, which, in turn, enable the optimization and maintenance of behaviors [9].

Since the study by Riley et al [4] was published, it is unclear how many smartphone-based interventions targeting PA and SB have integrated nonpsycholgical theories to create more dynamic models for digital behavior change interventions, what adaptive factors have been considered, and whether these dynamic interventions improve behaviors. Therefore, this review aims to (1) quantify the number of studies that have used integrated dynamic models to develop smartphone-based interventions to promote $\mathrm{PA}$ and reduce $\mathrm{SB},(2)$ describe their features, and (3) evaluate their effectiveness, where possible.

\section{Methods}

\section{Design}

The systematic review was performed according to the PRISMA (Preferred Reporting Items for Systematic Reviews and Meta-Analyses) statement [13] and was registered with PROSPERO (International Prospective Register of Systematic Reviews; CRD42020139350) [14].

\section{Study Criteria}

This review included studies that developed or evaluated digital behavior change interventions targeting PA, SB, or both and integrated psychological theories with dynamic theories and computational models (eg, control systems engineering); were either adaptive or just-in-time adaptive interventions that included smartphones for delivery; involved human adult participants; included randomized controlled trials (RCTs), pilot RCTs, quasi-experimental, pre-post study designs; and were published from 2000 onward.

\section{Exclusion Criteria}

Studies that used conventional theories of behavior change alone without integration with dynamic theories or computational models, case studies, protocols, conference abstracts, dissertations, and reviews were excluded.

\section{Definition}

For this review, dynamic theories refer to dynamic models taken from other disciplines, including engineering (eg, control systems engineering) and computer science (eg, agent-based modeling). The defining features of dynamic approaches are that they are not static, nonlinear in nature, and capable of 
capturing complex and rapid changes in behaviors (ie, time-variant) and their influential factors (ie, multivariate). Furthermore, they are quantifiable, empirical, and testable models.

\section{Search Strategy}

Databases (IEEE, PubMed, PsycINFO, Cochrane, and Scopus) were searched from January 2000 to May 15, 2019, without language restriction. Keywords (including Medical Subject Headings terms) and phrases comprised 3 components (mHealth, dynamic models, and activity), where "OR" and "AND" Boolean operators were used for within and between component searching (Multimedia Appendix 1). The wild-card term "** was used where necessary to potentiate sensitivity. Snowball searching was performed using the included studies to identify additional relevant research. The search results were exported to a reference manager software (EndNote X9; Clarivate Analytics) for review and extraction.

\section{Screening Process and Data Extraction}

Two researchers (JMV and RDK) independently screened and reviewed the titles and abstracts to identify eligible studies. The full text of the included papers was assessed based on the study criteria. The following information was collected: author and year, country, study design, duration of the study, recruitment and setting, the population of the study, sample size, inclusion criteria, participant characteristics, dynamic model, theory or constructs integrated, and outcomes measured (SB and PA behaviors).

\section{Quality Assessment}

Two researchers (JMV and RDK) assessed the risk of bias. The Cochrane Handbook for Systematic Reviews of Interventions [15] was used to evaluate randomized studies for selection bias, detection bias, attrition bias, performance bias, and reporting bias as the main sources of bias. Other sources of bias were also considered. In addition, the Joanna Briggs Institute Critical Appraisal Checklist for Quasi-Experimental Studies [16] was used to assess nonrandomized studies. Where available, protocols and trial registry data were found for risk of bias assessment. Where multiple reports existed for the same study, data were extracted from all reports and expressed together. The authors were contacted for further information, as needed.

\section{Data Analysis}

The data were synthesized narratively to address the aims of this review. Given the heterogeneity of the included studies in terms of methodology, outcome measures, and statistical approaches, a meta-analysis of effectiveness data was not conducted. Instead, a synthesis without a meta-analysis method-vote counting based on the direction of effects-was used to synthesize data [17]. The effect direction is a standardized binary metric based on the observed benefit (positive) or harm (negative). Vote counting is based on effect direction and compares the number of positive effects with the number of negative effects on an outcome. An effect direction plot is used for the visual representation of data and linking narrative synthesis to the overall conclusion $[18,19]$. In this review, the updated method of the effect direction plot is used as outlined elsewhere [20]. Changes within the intervention arm of controlled studies and changes from baseline in uncontrolled studies were considered for judgment. PA outcomes including light activity, walking (time and steps), moderate-to-vigorous PA (MVPA), nonwalking exercise, and total PA time from 6 studies were grouped as PA health domains. For studies with multiple PA outcomes, the effect direction was where $70 \%$ or more of the outcomes reported a similar direction (positive or negative). If less than $70 \%$ of outcomes showed a similar direction, they were reported as conflicting findings or no clear effect. A sign test was applied to test any evidence of an effect across studies. A 2-tailed $P$ value was then calculated to show the probability of observing positive and negative findings for the PA health domain.

\section{Results}

\section{Overview}

A total of 1087 study reports were identified after removing duplicates. In addition, 9 studies were identified through a manual search. A total of 76 research articles underwent a full review, and 11 reports describing 8 studies were eligible and included in this systematic review. The characteristics of the included studies are summarized in Table 1. The inclusion process and reasons for exclusion are shown in the PRISMA flow diagram (Figure 1). The reasons for excluding 65 studies (in full-text review) are provided in Multimedia Appendix 2 [21-85]. 
Table 1. General characteristics of the included studies.

\begin{tabular}{|c|c|c|c|c|c|c|}
\hline Author (year) & Country & $\begin{array}{l}\text { Study design and } \\
\text { duration }\end{array}$ & $\begin{array}{l}\text { Recruitment set- } \\
\text { ting }\end{array}$ & Sample, $\mathrm{n}$ & Inclusion criteria & Participants' characteristics \\
\hline $\begin{array}{l}\text { Baretta et al } \\
(2019)[86]\end{array}$ & Italy & $\begin{array}{l}\text { Intervention develop- } \\
\text { ment; } 8 \text { weeks }\end{array}$ & $\begin{array}{l}\text { Indoor activity } \\
\text { settings (eg, } \\
\text { gyms) }\end{array}$ & 60 & Not described & $\begin{array}{ll}\text { - } & \text { People who did not } \\
\text { meet PAa guidelines } \\
\text { - } & \text { Age }(35-60 \text { years }) \\
\text { - } & \text { Female }(35 / 60,58 \%)\end{array}$ \\
\hline $\begin{array}{l}\text { Conroy et al } \\
(2018)[12]\end{array}$ & $\begin{array}{l}\text { United } \\
\text { States }\end{array}$ & $\begin{array}{l}\text { Single-group mi- } \\
\text { crointervention; } 16 \\
\text { weeks }\end{array}$ & $\begin{array}{l}\text { Community (via } \\
\text { advertisement) }\end{array}$ & 10 & $\begin{array}{l}\text { Adults not meeting } \\
\text { federally recom- } \\
\text { mended levels of } \\
\text { aerobic PA but had } \\
\text { no contraindications } \\
\text { to PA }\end{array}$ & $\begin{array}{ll}\text { - } & \text { Mean age } 34.4(\mathrm{SD} \\
\text { 9.0) years } \\
\text { - } & \text { Female }(9 / 10,90 \%) \\
& \text { Employed full time } \\
& (8 / 10,80 \%) \\
\text { - } & \text { Parents }(6 / 10,60 \%) \\
\text { - } & \text { Single }(5 / 10,50 \%), \\
& \text { married }(4 / 10,40 \%), \text { or } \\
\text { divorced }(1 / 10,10 \%) \\
\text { Education }(6 / 10,60 \% \\
\text { with at least a bache- } \\
\text { lor's degree) } \\
\text { White (9/10, 90\%), } \\
\text { Asian American }(1 / 10, \\
\text { 10\%), and none were } \\
\text { Hispanic or Latino }\end{array}$ \\
\hline $\begin{array}{l}\text { Middelweerd et } \\
\text { al (2020) [89] } \\
\text { (Other related } \\
\text { references: } \\
\text { Klein et al [90] } \\
\text { and Middel- } \\
\text { weerd et al } \\
\text { [91]) }\end{array}$ & $\begin{array}{l}\text { The Nether- } \\
\text { lands }\end{array}$ & $\begin{array}{l}\text { 3-arm quasi-experi- } \\
\text { mental; } 12 \text { weeks }\end{array}$ & $\begin{array}{l}\text { Community (fly- } \\
\text { ers, posters, so- } \\
\text { cial media, per- } \\
\text { sonal contacts, } \\
\text { and snowball } \\
\text { strategies) }\end{array}$ & 104 & $\begin{array}{l}\text { Adults aged 18-30 } \\
\text { years at the time of } \\
\text { registration, in pos- } \\
\text { session of a suitable } \\
\text { smartphone running } \\
\text { on Android or iOS, } \\
\text { apparently healthy, } \\
\text { Dutch-speaking, and } \\
\text { signed the informed } \\
\text { consent form }\end{array}$ & $\begin{array}{ll}\text { - } & \text { Healthy young adults } \\
\text { - } & \text { Mean age } 23.4 \text { (SD } \\
& 3.0) \text { years } \\
\text { - } & \text { Female }(83 / 104, \\
& 79.8 \%) \\
\text { - } & \text { Students }(72 / 104, \\
& 69.2 \%) \\
\text { - } & \text { Mean BMI } 22.8 \text { (SD } \\
\text { - } 3.4) \mathrm{kg} / \mathrm{m} 2 \\
\text { Previous experience } \\
\text { with PA apps }(33 / 104, \\
\text { 31.7\%) }\end{array}$ \\
\hline $\begin{array}{l}\text { Korinek et al } \\
\text { (2018) [92] } \\
\text { (other related } \\
\text { references: } \\
\text { Freigoun et al } \\
\text { [93] and Martin } \\
\text { et al [22]) }\end{array}$ & $\begin{array}{l}\text { United } \\
\text { States }\end{array}$ & $\begin{array}{l}\text { Pre-post single-arm } \\
\text { intervention; } 14 \\
\text { weeks }\end{array}$ & $\begin{array}{l}\text { Nationally via } \\
\text { community adver- } \\
\text { tising methods } \\
\text { (eg, email to stu- } \\
\text { dent listservs, } \\
\text { word-of-mouth, } \\
\text { and social media } \\
\text { ads) }\end{array}$ & 20 & $\begin{array}{l}\text { Generally healthy, } \\
\text { insufficiently active, } \\
40 \text { to } 65 \text { years, BMI } \\
25 \text { to } 45 \mathrm{~kg} / \mathrm{m}^{2} \text {, } \\
\text { owned and regularly } \\
\text { used an Android } \\
\text { phone capable of } \\
\text { connecting to a Fit- } \\
\text { bit Zip via Bluetooth } \\
4.0\end{array}$ & $\begin{array}{ll}\text { - } & \text { Overweight and seden- } \\
\text { - } & \text { Age }(47 \text { years }) \\
\text { - } & \text { Mean BMI } 33.8(\mathrm{SD} \\
& 6.82) \mathrm{kg} / \mathrm{m} 2 \\
\text { - } & \text { Female }(18 / 20,90 \%) \\
\text { - } & \text { Walked on average } \\
& 4863 \text { steps per day }\end{array}$ \\
\hline
\end{tabular}




\begin{tabular}{|c|c|c|c|c|c|c|}
\hline Author (year) & Country & $\begin{array}{l}\text { Study design and } \\
\text { duration }\end{array}$ & $\begin{array}{l}\text { Recruitment set- } \\
\text { ting }\end{array}$ & Sample, $\mathrm{n}$ & Inclusion criteria & Participants' characteristics \\
\hline $\begin{array}{l}\text { Rabbi et al } \\
(2015)[94]\end{array}$ & $\begin{array}{l}\text { United } \\
\text { States }\end{array}$ & Pilot $\mathrm{RCT}^{\mathrm{b}} ; 3$ weeks & $\begin{array}{l}\text { Advertisement } \\
\text { placed through- } \\
\text { out the university } \\
\text { campus }\end{array}$ & $\begin{array}{l}17 \text { (intervention=9; } \\
\text { control=8) }\end{array}$ & $\begin{array}{l}\text { Owned an Android } \\
\text { mobile phone, inter- } \\
\text { ested in fitness }\end{array}$ & $\begin{array}{ll}\text { - } & \text { Adult students and } \\
\text { staff } \\
\text { - } & \text { Mean age } 28.3(\mathrm{SD} \\
& 6.96) \text { years } \\
\text { - } & \text { Student }(13 / 17,76 \%) \\
\text { - } & \text { Female }(8 / 17,47 \%) \\
\text { - } & \text { All participants (low- } \\
& \text { to-moderate PA) }\end{array}$ \\
\hline $\begin{array}{l}\text { Rabbi et al } \\
(2018) \text { [95] }\end{array}$ & $\begin{array}{l}\text { United } \\
\text { States }\end{array}$ & $\begin{array}{l}\text { Pilot Pre-post single- } \\
\text { arm intervention; } 5 \\
\text { weeks }\end{array}$ & $\begin{array}{l}\text { Via the Wellness } \\
\text { Center and retiree } \\
\text { mailing lists from } \\
\text { Cornell Universi- } \\
\text { ty }\end{array}$ & 10 & $\begin{array}{l}\text { People with a histo- } \\
\text { ry of chronic back } \\
\text { pain ( } \geq 6 \text { months in } \\
\text { duration); willing to } \\
\text { use MyBehavior- } \\
\text { CBP; having some } \\
\text { reasonable level of } \\
\text { outdoor movement } \\
\text { (eg, traveling to and } \\
\text { from work); not be- } \\
\text { ing significantly } \\
\text { housebound; with a } \\
\text { basic level of mobile } \\
\text { phone proficiency; } \\
\text { aged between } 18 \\
\text { years and } 65 \text { years; } \\
\text { and fluent in English }\end{array}$ & $\begin{array}{l}\text { - } \\
\text { - } \quad \text { low back pain } \\
\text { Mean age } 41.1(\mathrm{SD} \\
11.3 \text {; range } 31-60) \\
\text { years } \\
\text { - } \quad \text { Female }(7 / 10,70 \%)\end{array}$ \\
\hline $\begin{array}{l}\text { Zhou et al } \\
\text { (2018) [96] }\end{array}$ & $\begin{array}{l}\text { United } \\
\text { States }\end{array}$ & RCT; 10 weeks & $\begin{array}{l}\text { Email announce- } \\
\text { ment; university } \\
\text { campus }\end{array}$ & $\begin{array}{l}64 \text { (intervention=34; } \\
\text { control }=30)\end{array}$ & $\begin{array}{l}\text { Staff member, in- } \\
\text { tended to be physi- } \\
\text { cally active in the } \\
\text { next } 10 \text { weeks; own } \\
\text { an iPhone } 5 \text { s or } \\
\text { newer; willing to } \\
\text { keep the phone in } \\
\text { the pocket during } \\
\text { the day; willing to } \\
\text { install and use the } \\
\text { study App; able to } \\
\text { read and speak En- } \\
\text { glish }\end{array}$ & $\begin{array}{l}\text { - } \quad \begin{array}{l}\text { Adult staff employees } \\
\text { - }\end{array} \text { fmall fraction had the } \\
\text { following conditions: } \\
\text { high blood pressure } \\
(5 / 64,8 \%) \text {, type } 2 \text { dia- } \\
\text { betes }(5 / 64,8 \%) \text {, hyper- } \\
\text { cholesterolemia }(7 / 64, \\
11 \%) \\
\text { Married or cohabitating } \\
\text { - } 34 / 64,56 \%) \\
\text { White or non-Hispanic } \\
\text { - } 29 / 64,45 \%) \\
\text { Full-time job }(45 / 64, \\
\text { 70\%) } \\
\text { Mean age } 41.1(\mathrm{SD} \\
11.3) \text { years } \\
\text { Female }(53 / 64,83 \%)\end{array}$ \\
\hline
\end{tabular}

${ }^{\mathrm{a}} \mathrm{PA}$ : physical activity.

${ }^{b} \mathrm{RCT}$ : randomized controlled trial. 
Figure 1. Flow of studies. PRISMA: Preferred Reporting Items for Systematic Reviews and Meta-Analyses [13].

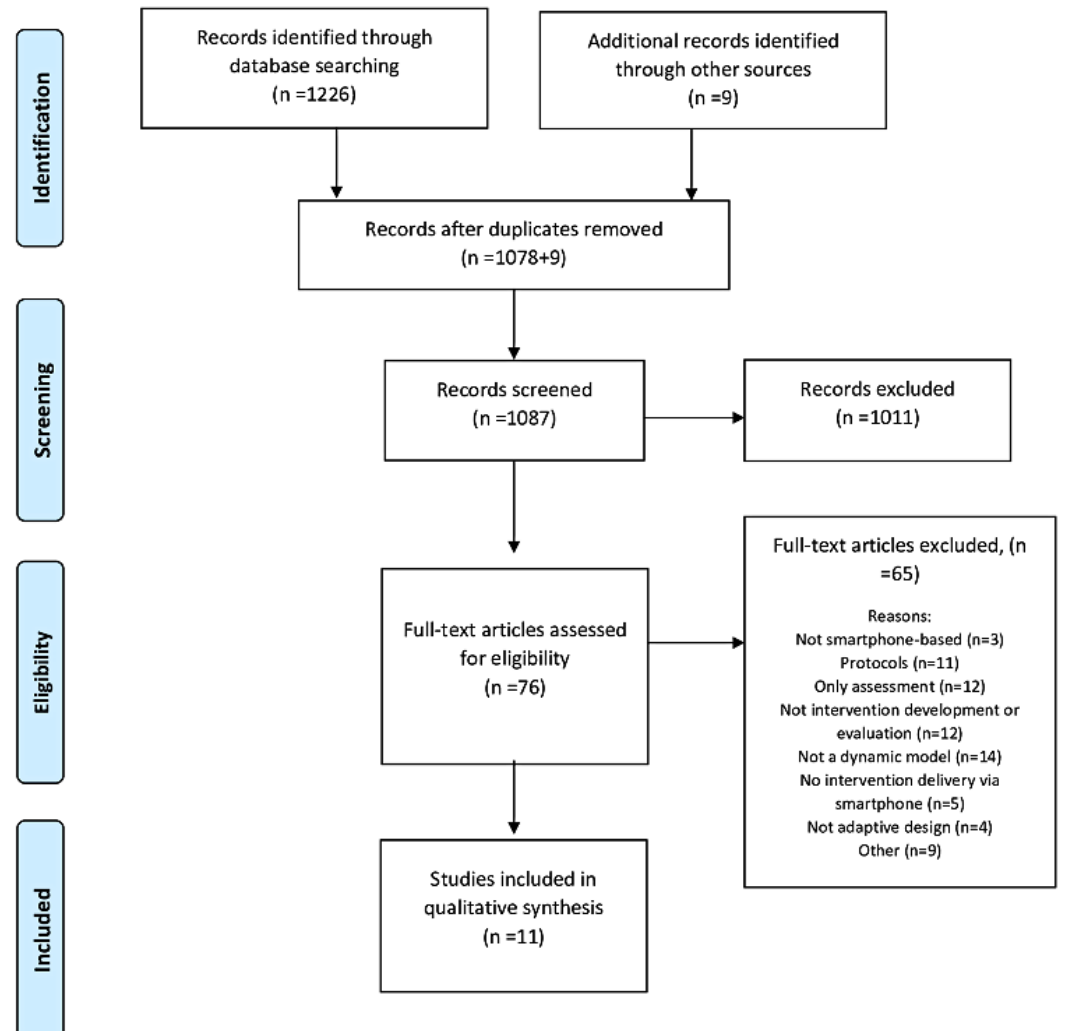

\section{General Description of the Studies}

A total of 5 studies were conducted in the United States [12,92,94-96], 1 in Italy [86], 1 in New Zealand [87,88], and 1 in the Netherlands [89-91]. Of these, 3 studies used pre-post intervention designs [87,92,95], 2 were RCTs [94,96], 1 was a 3-arm quasi-experimental study [89], 1 was a single-group microrandomized trial [12], and 1 was development study [86]. The duration of the studies ranged from 3 weeks to 6 months. A total of 5 studies recruited participants from community settings [12,86,87,89], 1 from the university campus and community [92], 2 from the university only [94,96], and 1 from a university wellness center and retiree mailing list [95]. Populations included insufficiently active and sedentary healthy adults, healthy and highly educated young adults, overweight and sedentary adults, adults with chronic low back pain, and students and staff from a university setting. Sample sizes ranged from 10 to 104 participants in the intervention evaluation studies and 60 in the development study. Participants were predominantly women in all studies except one [94]. The general characteristics of the included studies are summarized in Table 1 .

\section{Theoretical Premise}

SCT was the predominant psychological theory used [12,89,92,94,95]. A study incorporated self-efficacy theory [86], with a dynamic decision network - a sequence of simple Bayesian networks used to describe probabilistic computational models [97]. A study used an integrated behavior change model incorporating 33 behavior change techniques (eg, self-monitoring, goal setting, and review of goals) combined with the behavioral intervention technology model [87]. Two studies incorporated control systems engineering models integrated with SCT [12,92]. In a study, SCT, self-regulation theory, and health action process approaches were integrated with a computational agent model-an intelligent reasoning system [89]. Learning theory, the Fogg behavior model, and SCT were combined with the exploit-explore strategy in 2 studies [94,95]. Rather than using a theoretical framework, a study integrated a single behavior change technique (goal setting) with a behavioral analytic algorithm [96].

\section{Featured Description of Interventions}

All studies promoted PA, whereas 4 studies also involved interventions for reducing SB [12,87,94,95]. Few studies explicitly stated the inclusion of behavior change techniques $[87,89,92]$ as part of their intervention, 2 of which included a range of behavior change techniques [87,89]. Conroy et al [12] did not describe specific behavior change techniques but stated using intervention messages, which targeted key SCT constructs (eg, outcome expectancies, risk awareness and planning, efficacy-building affirmations, social support, and evoking anticipated reward or regret). The most common behavior change technique used across all studies was goal setting $[86,87,89,92,96]$. In terms of PA, 3 studies $[87,92,96]$ included daily goal setting to achieve PA targets, whereas 1 study promoted weekly goal setting [89]. In a study, weekly step goals were initially established and then broken down into daily short-term goals [86]. Only 1 study set goals for SB [87]. To help participants set PA and SB goals, 5 studies used past activity performance $[86,87,89,92,96]$, whereas 2 also took into account individuals' perceptions of self-efficacy [86,92]. Instead of setting goals, 2 studies focused on habit formation by providing suggestions from an individual's past frequent and infrequent activities after manual and automatic logging and 
clustering of past activities [94,95]. Habit formation was also accounted for in another study [87]. For SB, Direito et al [87] encouraged participants to replace periods of extended sedentary time with light-intensity walking and standing, whereas Conroy et al [12] included sit less and move more messages. Two other studies by Rabbi et al $[94,95]$ targeted both SB and standing by promoting short walks. None of the studies measured standing as an outcome.

Monitoring and feedback on behavior was another widely used behavior change technique $[86,87,89,92,94,96]$. All 6 studies used visual and numerical feedback on behavior, whereas 2 used biofeedback to help monitor behavior [86,94]. Four studies included a reward in the form of social rewards $[19,20,94]$ and material incentives [17]. In terms of the type of intervention, 2 studies used push notification messages [87,89], 3 used push notifications to present step goals or minutes of activity goals (eg, walking) [86,92,96], 2 had in-app suggestions selected from frequent and infrequent past activities [94,95], and 1 used text messages [12].

In total, 7 studies used mobile apps, 6 of which ran on Android $[86,87,89,92,94,95]$ and 1 on iPhone operating systems (iOS) [96]; 1 study did not mention the operating system used [12]. Four studies including TODAY, MyBehavior, MyBehaviorCBP, and CalFit [87,94-96] used built-in smartphone sensors (ie, accelerometers) to measure activity, and 3 studies used wearable activity trackers (Fitbit One, Fitbit Zip, and ActivPAL3) $[12,89,92]$. A heart rate sensor was used to measure activity in the study by Baretta et al [86]. Furthermore, 3 studies used the phone GPS to identify geo-locations $[89,94,95]$. Some studies used built-in phone GPS and apps to capture and account for environmental contexts such as location (eg, workplace) $[87,89,94,95]$, weather $[89,92]$, and weekend or weekday $[12,92]$. The JustWalk intervention incorporated psychological states (eg, stress) and measures of busyness and sleep quality. Further details have been provided in Table 2. 
Table 2. Features of smartphone-based physical activity intervention development or evaluation.

\begin{tabular}{|c|c|c|c|c|c|c|c|}
\hline $\begin{array}{l}\text { Author } \\
\text { (year) }\end{array}$ & Intervention & Control & $\begin{array}{l}\text { Theoretical } \\
\text { premise }\end{array}$ & $\begin{array}{l}\text { Primary } \\
\text { outcome }\end{array}$ & $\begin{array}{l}\text { Other out- } \\
\text { comes }\end{array}$ & Technology feature & Results \\
\hline $\begin{array}{l}\text { Baretta et } \\
\text { al (2019) } \\
{[86]}\end{array}$ & $\begin{array}{l}\text { Weekly tailored PA } \\
\text { goals } \\
\text { - } \\
\text { Starting goal } \\
\text { (first week): } 120 \\
\text { METb } \\
\text { Long-term goal: } \\
\text { 600 METs per } \\
\text { week of PA } \\
\text { Weekly goals } \\
\text { broken down in- } \\
\text { to daily goals } \\
\text { Factors not con- } \\
\text { sidered in the in- } \\
\text { tervention devel- } \\
\text { opment but pro- } \\
\text { posed for the } \\
\text { next study: } \\
\text { working hours, } \\
\text { time of the day, } \\
\text { day of the week, } \\
\text { health and ill- } \\
\text { ness, weather, } \\
\text { etc }\end{array}$ & $N / A^{c}$ & $\begin{array}{l}\text { Self-efficacy } \\
\text { theory and dy- } \\
\text { namic deci- } \\
\text { sion network }\end{array}$ & $\begin{array}{l}\text { PA mea- } \\
\text { sured by } \\
H^{d}{ }^{d} \text { sen- } \\
\text { sor, self-ef- } \\
\text { ficacy be- } \\
\text { liefs }\end{array}$ & N/A & $\begin{array}{l}\text { Android app: } \\
\text { Muoviti (visualiz- } \\
\text { ing the heart-beat } \\
\text { rate graph of the } \\
\text { last training ses- } \\
\text { sion, the curves of } \\
\text { weight and waist- } \\
\text { line variations } \\
\text { week by week, the } \\
\text { burned calories } \\
\text { graph, session by } \\
\text { session, and the } \\
\text { percentage of vig- } \\
\text { orous activity with } \\
\text { respect to moder- } \\
\text { ate activity) } \\
\text { Other: HR wrist- } \\
\text { bands (MioAlpha } \\
\text { and PulseON) }\end{array}$ & - $\quad$ N/A \\
\hline $\begin{array}{l}\text { Direito et } \\
\text { al }(2018 \\
\text { and 2019) } \\
{[87,88]}\end{array}$ & $\begin{array}{l}\text { Daily individualized } \\
\text { and adaptive PA and } \\
\text { SB } \text { goals: } \\
\text { Daily activities } \\
\text { (eg, transport to } \\
\text { or from work, } \\
\text { PA at work) } \\
\text { Light-intensity } \\
\text { activity to re- } \\
\text { place SB (eg, } \\
\text { walking to a col- } \\
\text { league's desk } \\
\text { rather than call } \\
\text { or email, stand } \\
\text { up while on the } \\
\text { phone) } \\
\text { Leisure-time } \\
\text { moderate-to-vig- } \\
\text { orous PA (eg, } \\
\text { cycling) } \\
\text { Daily goals, visu- } \\
\text { al and numerical } \\
\text { feedback on past } \\
\text { day and histori- } \\
\text { cal data, tips or } \\
\text { suggestions, info- } \\
\text { graphics, videos, } \\
\text { and links, fre- } \\
\text { quently asked } \\
\text { questions, re- } \\
\text { minders, and } \\
\text { push notifica- } \\
\text { tions } \\
\text { - }\end{array}$ & N/A & $\begin{array}{l}\text { Intervention } \\
\text { mapping tax- } \\
\text { onomy to } \\
\text { identify behav- } \\
\text { ior change } \\
\text { techniques } \\
\text { (eg, self-moni- } \\
\text { toring, goal } \\
\text { setting, or re- } \\
\text { view of goals) } \\
\text { from litera- } \\
\text { ture. Integrat- } \\
\text { ed behavior } \\
\text { change model } \\
\text { constructs and } \\
\text { behavioral in- } \\
\text { tervention } \\
\text { technology; } \\
33 \text { behavior } \\
\text { change tech- } \\
\text { niques were } \\
\text { included }\end{array}$ & $\begin{array}{l}\text { Test the ac- } \\
\text { ceptability } \\
\text { and feasibil- } \\
\text { ity of just- } \\
\text { in-time } \\
\text { adaptive in- } \\
\text { tervention } \\
\text { on PA and } \\
\text { SB }\end{array}$ & $\begin{array}{l}\text { Pilot-test- } \\
\text { ing the TO- } \\
\text { DAY }^{\mathrm{f}} \text { app }\end{array}$ & $\begin{array}{l}\text { Android apps: Art } \\
\text { of Living app and } \\
\text { TODAY app. Oth- } \\
\text { er: built-in phone } \\
\text { sensors for SB and } \\
\text { activity (ie, ac- } \\
\text { celerometer) }\end{array}$ & $\begin{array}{l}\text { TODAY app: low- } \\
\text { effort and pleasant } \\
(54.3 \%) \text {, provides } \\
\text { guidance on } \\
\text { changing activity } \\
\text { profile }(52.6 \%), \\
\text { positively framed } \\
\text { messages (64.4\%), } \\
\text { the app sustained } \\
\text { interest over the } 8 \\
\text { weeks (28.8\%) } \\
\text { Most favorable } \\
\text { behavior change } \\
\text { techniques for the } \\
\text { users (goal setting, } \\
\text { discrepancy be- } \\
\text { tween current be- } \\
\text { havior and goal, } \\
\text { feedback on behav- } \\
\text { ior, instruction on } \\
\text { how to perform } \\
\text { the behavior, and } \\
\text { behavior substitu- } \\
\text { tion) } \\
\text { Only significant } \\
\text { improvement was } \\
\text { occurred on light } \\
\text { PA (see the results } \\
\text { for statistics) }\end{array}$ \\
\hline
\end{tabular}




\begin{tabular}{|c|c|c|c|c|c|c|c|}
\hline $\begin{array}{l}\text { Author } \\
\text { (year) }\end{array}$ & Intervention & Control & $\begin{array}{l}\text { Theoretical } \\
\text { premise }\end{array}$ & $\begin{array}{l}\text { Primary } \\
\text { outcome }\end{array}$ & $\begin{array}{l}\text { Other out- } \\
\text { comes }\end{array}$ & Technology feature & Results \\
\hline $\begin{array}{l}\text { Conroy et } \\
\text { al (2018) } \\
{[12]}\end{array}$ & $\begin{array}{l}\text { Five daily text mes- } \\
\text { sages (between } 8 \text { AM } \\
\text { to } 8 \text { PM). Three mes- } \\
\text { sage types (move } \\
\text { more, sit less, general } \\
\text { facts or trivia [unrelat- } \\
\text { ed to PA or SB]). } \\
\text { Message receipt was } \\
\text { confirmed with a re- } \\
\text { ply. Factors: context } \\
\text { (weekday and week- } \\
\text { end) }\end{array}$ & N/A & $\begin{array}{l}\text { Social cogni- } \\
\text { tive theory } \\
\text { and control } \\
\text { systems engi- } \\
\text { neering }\end{array}$ & $\begin{array}{l}\text { Stepping } \\
\text { time }\end{array}$ & N/A & $\begin{array}{l}\text { - } \\
\text { me app or text } \\
\text { - ActivPage } \\
\text { ity tracker) }\end{array}$ & $\begin{array}{l}\text { - Proof-of-concept } \\
\text { study) 50\% of the } \\
\text { sample: more pro- } \\
\text { nounced behav- } \\
\text { ioral responses to } \\
\text { text messages on } \\
\text { weekends than } \\
\text { weekdays; 50\% } \\
\text { had similar week- } \\
\text { end or weekday } \\
\text { responses; 50\% of } \\
\text { responders in- } \\
\text { creased stepping } \\
\text { time in response to } \\
\text { "move more" } \\
\text { messages, and } \\
\text { 50\% increased } \\
\text { stepping time in } \\
\text { response to "sit } \\
\text { less" messages }\end{array}$ \\
\hline $\begin{array}{l}\text { Middel- } \\
\text { weerd et al } \\
(2020) \\
\text { [89], Klein } \\
\text { et al (2017) } \\
\text { [90], and } \\
\text { Middel- } \\
\text { weerd et al } \\
\text { (2018) [91] }\end{array}$ & $\begin{array}{l}\text { Weekly moderate-to- } \\
\text { vigorous PA goals: } 30 \\
\text { minutes of moderate } \\
\text { PA for at least } 5 \text { days } \\
\text { a week or } 20 \text { minutes } \\
\text { of vigorous PA for } 3 \\
\text { days a week } \\
\text { Contexts (location, } \\
\text { weather, occupation) } \\
\text { Connected friends } \\
\text { (Facebook API }{ }^{\mathrm{g}} \text { ), if } 2 \\
\text { participants of the in- } \\
\text { tervention are connect- } \\
\text { ed } \\
\text { Up to } 3 \text { messages a } \\
\text { day }\end{array}$ & N/A & $\begin{array}{l}\text { Social cogni- } \\
\text { tive theory, } \\
\text { self-regulation } \\
\text { theory and } \\
\text { health action } \\
\text { process ap- } \\
\text { proach and } \\
\text { computational } \\
\text { agent model }\end{array}$ & $\begin{array}{l}\text { To increase } \\
\text { the total } \\
\text { time spent } \\
\text { in moder- } \\
\text { ate-to-vig- } \\
\text { orous PA }\end{array}$ & N/A & $\begin{array}{l}\text { Android app: Ac- } \\
\text { tive2Gether } \\
\text { Fitbit One (for } \\
\text { self-monitoring } \\
\text { only), ActiGraph } \\
\text { wGT3XBT and } \\
\text { GT3X+ (activity } \\
\text { trackers) }\end{array}$ & $\begin{array}{l}\text { No significant in- } \\
\text { tervention effects } \\
\text { were found for the } \\
\text { Active2Gether-full } \\
\text { and Active2Geth- } \\
\text { er-ight conditions } \\
\text { on levels of PA } \\
\text { compared with the } \\
\text { Fitbit condition: } \\
\text { larger effect size } \\
\text { for Active } 2 \text { Geth- } \\
\text { er-ight }(\beta=3.1, \\
95 \% \text { CI }-6.66 \text { to } \\
12.78, \text { for minutes } \\
\text { of moderate-to- } \\
\text { vigorous PA; } \\
\beta=5.2,95 \% \text { CI } \\
-1334 \text { to } 1345, \text { for } \\
\text { steps). Smaller ef- } \\
\text { fect size for Ac- } \\
\text { tive2Gether-full } \\
\text { ( } \beta=1.2,95 \% \text { CI } \\
-8.7 \text { to } 11.1, \text { for } \\
\text { minutes of moder- } \\
\text { ate-to-vigorous } \\
\text { PA; } \beta=-389,95 \% \\
\text { CI }-1750 \text { to } 972, \\
\text { for steps) }\end{array}$ \\
\hline $\begin{array}{l}\text { Korinek et } \\
\text { al (2018) } \\
\text { [92] and } \\
\text { Freigoun et } \\
\text { al (2017) } \\
\text { [93]. More } \\
\text { informa- } \\
\text { tion is } \\
\text { available in } \\
\text { Martin et al } \\
\text { (2018) [22] }\end{array}$ & & N/A & $\begin{array}{l}\text { Social cogni- } \\
\text { tive theory } \\
\text { (particularly } \\
\text { self-efficacy } \\
\text { construct), } \\
\text { goal setting } \\
\text { and control } \\
\text { systems engi- } \\
\text { neering (sys- } \\
\text { tem identifica- } \\
\text { tion) }\end{array}$ & $\begin{array}{l}\text { Feasibility, } \\
\text { daily steps }\end{array}$ & N/A & $\begin{array}{ll}\text { - } & \text { Android app: Just- } \\
\text { Walk } \\
\text { - } \\
\text { Fitbit Zip (activity } \\
\text { tracker) } \\
\text { Other: web-based } \\
\text { mobile question- } \\
\text { naire }\end{array}$ & \\
\hline
\end{tabular}




\begin{tabular}{|c|c|c|c|c|c|c|c|}
\hline $\begin{array}{l}\text { Author } \\
\text { (year) }\end{array}$ & Intervention & Control & $\begin{array}{l}\text { Theoretical } \\
\text { premise }\end{array}$ & $\begin{array}{l}\text { Primary } \\
\text { outcome }\end{array}$ & $\begin{array}{l}\text { Other out- } \\
\text { comes }\end{array}$ & Technology feature & Results \\
\hline & $\begin{array}{l}\text { Daily step goal: } \\
\text { Pseudorandomly } \\
\text { assigned daily } \\
\text { step goal (doable } \\
\text { [based on base- } \\
\text { line median daily } \\
\text { step] and ambi- } \\
\text { tious [ie, up to } \\
\text { 2.5×baseline me- } \\
\text { dian])+ rewards } \\
\text { (points>Amazon } \\
\text { Gift Cards) } \\
\text { Six 16-day cy- } \\
\text { clesh (cycle } 0 \\
\text { [baseline], cycles } \\
1 \text { to } 5 \text { [step goals } \\
\text { assigned]) } \\
\text { Step goals } \\
\text { prompted every } \\
\text { morning+there } \\
\text { were daily, } \\
\text { weekly and } \\
\text { monthly surveys } \\
\text { Morning and } \\
\text { evening EMAi } \\
\text { assessed con- } \\
\text { structs including } \\
\text { (eg, confidence } \\
\text { in achieving the } \\
\text { goal, predicted } \\
\text { busyness for that } \\
\text { stress, perceived } \\
\text { day, previous } \\
\text { night's sleep } \\
\text { er informatity) } \\
\text { sleep quality } \\
\text { - }\end{array}$ & & & & & & 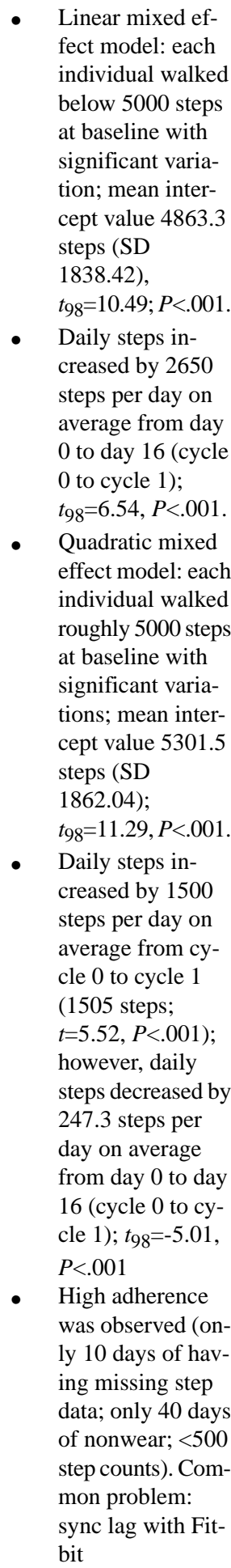 \\
\hline $\begin{array}{l}\text { Rabbi et al } \\
(2015) \text { [94] }\end{array}$ & & $\begin{array}{l}\text { Nonpersonal- } \\
\text { ized generic } \\
\text { recommenda- } \\
\text { tions }\end{array}$ & $\begin{array}{l}\text { Learning theo- } \\
\text { ry, Fogg be- } \\
\text { havior model, } \\
\text { social cogni- } \\
\text { tive theory, } \\
\text { and exploit- } \\
\text { explore strate- } \\
\mathrm{gy}^{\mathrm{j}}\end{array}$ & $\begin{array}{l}\text { Adherence, } \\
\text { acceptabili- } \\
\text { ty, behav- } \\
\text { ior change }\end{array}$ & N/A & $\begin{array}{l}\text { Android app: My- } \\
\text { Behavior; other: } \\
\text { phone accelerome- } \\
\text { ter and GPS }\end{array}$ & \\
\hline
\end{tabular}




\begin{tabular}{|c|c|c|c|c|c|c|c|}
\hline $\begin{array}{l}\text { Author } \\
\text { (year) }\end{array}$ & Intervention & Control & $\begin{array}{l}\text { Theoretical } \\
\text { premise }\end{array}$ & $\begin{array}{l}\text { Primary } \\
\text { outcome }\end{array}$ & $\begin{array}{l}\text { Other out- } \\
\text { comes }\end{array}$ & Technology feature & Results \\
\hline & $\begin{array}{l}\text { Daily personalized } \\
\text { context-sensitive sug- } \\
\text { gestions (PA and sta- } \\
\text { tionery). Manual and } \\
\text { automatic logging to } \\
\text { track activity and user } \\
\text { location. Start of each } \\
\text { day: } 10 \text { in-app activity } \\
\text { suggestions ( } 90 \% \\
\text { users' most frequent } \\
\text { activities [exploit]; } \\
\text { 10\% from users' infre- } \\
\text { quent activities [ex- } \\
\text { plore]). MyBehavior } \\
\text { app included both PA } \\
\text { and dietary interven- } \\
\text { tions }\end{array}$ & & & & & & $\begin{array}{l}\text { Intervention partic- } \\
\text { ipants more intend- } \\
\text { ed to follow per- } \\
\text { sonalized sugges- } \\
\text { tions than control } \\
\text { (effect size=0.99, } \\
95 \% \text { CI } 0 \text { to } \\
1.001 ; P<.001) \text {. } \\
\text { Most intervention } \\
\text { participants (78\%) } \\
\text { had a positive } \\
\text { trend in walking } \\
\text { behavior (also in- } \\
\text { creased daily } \\
\text { walking by } 10 \\
\text { minutes during the } \\
\text { intervention), } \\
\text { whereas most con- } \\
\text { trol participants } \\
\text { (75\%) showed a } \\
\text { negative trend. } \\
\text { The users found } \\
\text { MyBehavior app } \\
\text { suggestion very } \\
\text { actionable and } \\
\text { wanted to follow } \\
\text { them }\end{array}$ \\
\hline $\begin{array}{l}\text { Rabbi et al } \\
(2018) \text { [95] }\end{array}$ & $\begin{array}{l}\text { Context-sensitive sug- } \\
\text { gestions (PA and sta- } \\
\text { tionery). Manual and } \\
\text { automatic logging to } \\
\text { track activity and user } \\
\text { location. In-app sug- } \\
\text { gestions ( } 80 \% \text { users' } \\
\text { most frequent activi- } \\
\text { ties [exploit]; } 20 \% \\
\text { from users' infrequent } \\
\text { activities [explore]); } \\
\text { total time for each se- } \\
\text { lected activity must } \\
\text { not exceed } 60 \text { min- } \\
\text { utes. End of day re- } \\
\text { ward score }\end{array}$ & $\begin{array}{l}\text { Static sugges- } \\
\text { tions }\end{array}$ & $\begin{array}{l}\text { Learning theo- } \\
\text { ry, Fogg be- } \\
\text { havior model, } \\
\text { social cogni- } \\
\text { tive theory } \\
\text { (self-efficacy) } \\
\text { and exploit- } \\
\text { explore strate- } \\
\text { gy }\end{array}$ & $\begin{array}{l}\text { Use, accept- } \\
\text { ability, ear- } \\
\text { ly efficacy }\end{array}$ & $\begin{array}{l}\text { Qualitative } \\
\text { feedback }\end{array}$ & $\begin{array}{l}\text { Android app: My- } \\
\text { BehaviorCBP; } \\
\text { other: phone ac- } \\
\text { celerometer and } \\
\text { GPS }\end{array}$ & $\begin{array}{l}\text { Intervention condi- } \\
\text { tion increased dai- } \\
\text { ly walking by } 4.9 \\
\text { minutes ( } \beta=4.9 ; \\
P=.02 \text { ) significant- } \\
\text { ly. Exercise time } \\
\text { was increased } \\
\text { nonsignificantly } \\
\text { by } 9.5 \text { minutes } \\
\text { ( } \beta=9.5 ; P=.31) . \\
\text { MyBehaviorCBP } \\
\text { was opened } 3.2 \\
\text { times a day (on } \\
\text { average). MyBe- } \\
\text { haviorCBP sugges- } \\
\text { tions were per- } \\
\text { ceived as low-bur- } \\
\text { den }(\beta=.42 ; \\
P<.001) \text {. Back } \\
\text { pain was reduced } \\
\text { in the intervention } \\
\text { condition, but not } \\
\text { significantly } \\
\text { ( } \beta=-.19 ; P=.24) \text {. } \\
\text { Participants sug- } \\
\text { gested considera- } \\
\text { tion of weather, } \\
\text { weekend or week- } \\
\text { day, and level of } \\
\text { pain for future in- } \\
\text { terventions }\end{array}$ \\
\hline $\begin{array}{l}\text { Zhou et al } \\
(2018) \text { [96] }\end{array}$ & & $\begin{array}{l}\text { Steady step } \\
\text { goals }(10,000 \\
\text { per day) }\end{array}$ & $\begin{array}{l}\text { Goal setting } \\
\text { and behavioral } \\
\text { analytics algo- } \\
\text { rithm }^{\mathrm{k}}\end{array}$ & $\begin{array}{l}\text { Change in } \\
\text { daily step }\end{array}$ & & $\begin{array}{l}\text { iOS app: CalFit; } \\
\text { other: built-in } \\
\text { health chip in the } \\
\text { iPhone }\end{array}$ & \\
\hline
\end{tabular}




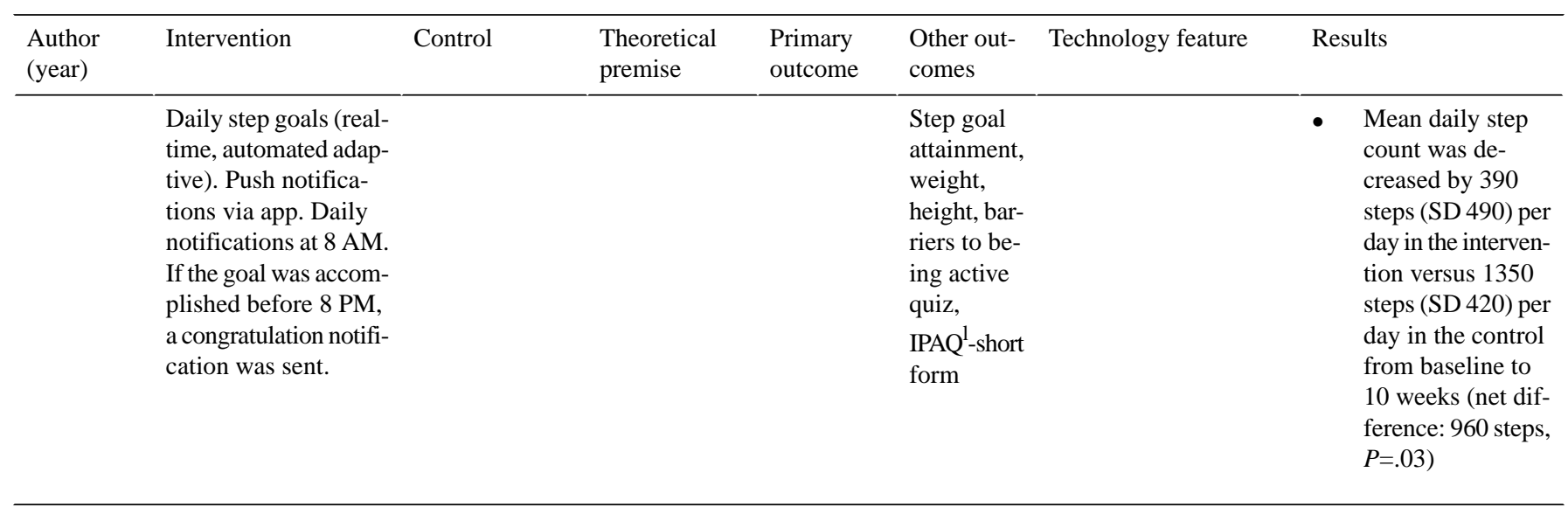

\footnotetext{
${ }^{\mathrm{a} P A:}$ physical activity.

${ }^{\mathrm{b}}$ MET: metabolic equivalents.

${ }^{\mathrm{c}} \mathrm{N} / \mathrm{A}$ : not applicable.

${ }^{\mathrm{d}} \mathrm{HR}$ : heart rate.

${ }^{\mathrm{e}} \mathrm{SB}$ : sedentary behavior.

${ }^{f}$ TODAY: Tailored Daily Activity.

${ }^{\mathrm{g}}$ API: application programming interface.

${ }^{\mathrm{h}}$ Step goals did not increase between cycles.

${ }^{\mathrm{i}}$ EMA: ecological momentary assessment.

${ }^{\mathrm{j}}$ Grounded in artificial intelligence and a subcategory of a broader decision-making framework called multiarmed bandit, which stems from probability theory.

${ }^{\mathrm{k}}$ Behavioral analytics algorithm uses machine learning to build a predictive model-based on historical and goal steps for a particular person and then uses this estimation to generate challenging yet realistic and adaptive step goals based on a predictive model that would maximize the physical activity in the future.

${ }^{1}$ IPAQ: International Physical Activity Questionnaire.
}

\section{Effectiveness of Interventions}

\section{Narrative Synthesis of Individual Studies}

A total of 6 studies reported on the effectiveness of the intervention $[87,89,92,94-96]$; the details are presented in Table 1. The intervention by Direito et al [87] increased the time spent in light and moderate-to-vigorous intensity PA and total PA time; however, only light-intensity PA achieved statistical significance from pre- to postintervention assessments (adjusted mean difference 2.2 minutes, SE of difference 1.0; 95\% CI 0.78-3.56; $P=.002$ ). A small, but statistically nonsignificant, decrease in SB was observed (adjusted mean difference -9.5 minutes, SE of difference 7.5; 95\% CI 19.98-1.05; $P=.08$ ). The Active2Gether intervention involved 3 arms of Active2Gether-full (tailored coaching messages, self-monitoring, and social comparison), Active2Gether-light (self-monitoring and social comparison), and Fitbit app control condition (self-monitoring). The Active2Gether did not show an effect on PA levels (average daily minutes of MVPA and step counts) compared with the Fitbit app ( $\beta=1.2,95 \%$ CI -8.7 to 11.1, $P=.81$, for minutes of MVPA; $\beta=-389,95 \%$ CI -1750 to 972 , $P=.57$, for steps and $\beta=3.1,95 \% \mathrm{CI}-6.66$ to $12.78, P=.53$, for minutes of MVPA; $\beta=5.2,95 \% \mathrm{CI}-1334$ to $1345, P=.99$, for steps, for the full and light app, respectively). The JustWalk intervention increased the average daily steps by 2650 steps in
16 days $\left(t_{98}=6.54 ; P<.001\right)$. This effect decreased from day 16 to day 96 (average daily change -109.1 steps; $\mathrm{t}_{98}=-1.42 ; P=.15$ ), suggesting acceptable maintenance. Users of the MyBehavior app walked an average of 10 minutes per day more from the first to the third week. There was no change in the control group (between-group differences were statistically significant $\left(t_{15}=2.1\right.$; $P=.06 ; 95 \% \mathrm{CI}-0.23$ to $19.05 ; d=0.9)$. In the second study by Rabbi et al [95], MyBehaviorCBP was associated with an increased daily walking time of 4.9 minutes ( $\beta=4.9 ; P=.02 ; 95 \%$ CI $0.8-0.89 ; d=0.31$ ) among adults with chronic back pain. Nonwalking exercise time also increased by 9.5 minutes, but it was not statistically significant $(\beta=9.5 ; P=.31 ; 95 \% \mathrm{CI}-6.3$ to $21.8 ; d=0.03$ ). The Cal Fitness trial showed that the mean daily step count decreased in the 10-week intervention for both the intervention (mean -390, SD 490) and control group (mean -1350 , SD 420; net mean difference 960; 95\% CI 90-1830; $P=.03$ ). The Conroy et al [12] study was conducted to determine proof-of-concept and did not report effectiveness data (for descriptive results, see Table 2).

\section{Effect Direction Plot}

This study included 6 interventional studies. Figure 2 shows the effect direction plot for the PA health outcome domain; 5 of 6 interventions reported a positive effect direction, with 1 study showing a negative effect on PA health. The $P$ value for the sign test for PA health was $P=.21$. 
Figure 2. Effect direction plot summarizing the direction of impact from smartphone-based physical activity interventions.

\begin{tabular}{|c|c|c|}
\hline Study & Study Design & PA health \\
\hline Direito $2019^{a}$ & UBA & $\boldsymbol{\Delta}_{3}$ \\
\hline Middleweerd $2020^{b}$ & CBA & $\mathbf{\Delta}_{2}$ \\
\hline Korinek 2018 & UBA & $\mathbf{\Delta}_{1}$ \\
\hline Rabbi 2015 & RCT & $\Delta$ \\
\hline Rabbi 2018 & UBA & $\mathbf{\Delta}_{2}$ \\
\hline Zhou 2018 & RCT & $\mathbf{\nabla}_{1}$ \\
\hline $\mathrm{P}$ value (two tailed) & & $0.2188^{*}$ \\
\hline \multicolumn{3}{|c|}{$\begin{array}{l}\text { LEGEND } \\
\text { Study design: RCT: Randomised Controlled Trial; UBA: Uncontrolled Before After; CBA: Controlled } \\
\text { Before After; etc. } \\
\text { Effect direction: upward arrow } \mathbf{\Lambda}=\text { positive health impact, downward arrow } \mathbf{\nabla}=\text { negative health impact, } \\
\text { sideways arrow }\end{array}$} \\
\hline \multicolumn{3}{|c|}{$\begin{array}{l}\text { Sample size: Final sample size (individuals) in intervention group Large arrow } \boldsymbol{\Lambda}>300 \text {; medium arrow } \\
\Delta 50-300 \text {; small arrow } \mathbf{\Delta}<50 \\
\text { Study quality: denoted by row colour: green=low risk of bias; amber=some concerns; red=high risk of } \\
\text { bias }\end{array}$} \\
\hline \multicolumn{3}{|c|}{ p value calculation was conducted via https://www.graphpad.com/quickcalcs/binomial1/1 } \\
\hline \multicolumn{3}{|c|}{ "This is the chance of observing either 5 or more successes, or 1 or fewer successes, in 6 trials } \\
\hline \multicolumn{3}{|c|}{ Subscripts show the number of outcomes considered for judgement. } \\
\hline dSedentary behaviour time re & Direito et al. (2019) was & om synthesis. \\
\hline
\end{tabular}

\begin{abstract}
Risk of Bias Assessment of the Included Interventions
Judgments on the risk of bias for the 2 RCTs and 4 quasi-experimental studies are presented in Multimedia Appendix 3 [12,87,89,92,94-96]. Overall, the included studies were of relatively high quality. The 2 RCTs $[94,96]$ were judged to be low risk in all domains except one (ie, blinding of participants and personnel). All included quasi-experimental studies lacked a control group because of a pre-post [87,92,95] or single-group intervention [12] design. These interventions did not introduce additional risks to the remaining eight domains.
\end{abstract}

\section{Discussion}

\section{Principal Findings}

This review aims to quantify the number of studies that have integrated traditional psychological theories with dynamic computational models in the development or evaluation of smartphone interventions to reduce SB and promote PA. Although we showed that a few studies-mainly pilot, feasibility, and proof-of-concept-have taken an integrated dynamic approach, there was no consensus on what dynamic model-based approach should be used and how. Overall, it was difficult to draw a conclusion on the effectiveness of the included smartphone interventions; however, preliminary findings on PA are promising, less so for SB. Moreover, an effect direction plot was used to illustrate the direction of the intervention effect on PA outcomes, regardless of their statistical significance.

This review was driven in part by a paper by Riley et al [4] who argued that to truly capture the benefits of smartphones to deliver real-time and adaptive interventions, they need to adopt principles from other disciplines, such as control systems engineering, and integrate them with traditional health behavior theories. In total, we found only 8 studies that had adopted this notion, most of which used SCT for integration, with considerable complexity in the approaches used, ranging from a basic use of behavioral analytic algorithms to a more sophisticated approach using control systems.

Advancements in smartphone technology have enabled the collection of intensive contextual and longitudinal (time-variant) data, which facilitate the delivery of automated, real-time, and adaptive behavior change interventions such as just-in-time adaptive interventions. These features permit the testing of specific intervention components (eg, behavioral messaging comprising behavior change techniques). Control systems appear to offer an excellent fit for the development of adaptive smartphone interventions. It explores ways to influence a dynamic system (eg, time-varying adaptive PA intervention) and how to regulate it $[11,12]$. In other words, control systems engineering provides a dynamic approach to designing tailored interventions that adapt over time and are based on real-time data (ie, intensive longitudinal data) [98]. Despite the variability in the application of dynamic models outlined in this review, existing evidence suggests that their integration with traditional behavior change and psychological theories offer exciting opportunities to better understand human behavior (eg, SB and PA), identify patterns of behavior, and optimize individually adapted behavior change interventions.

Few of the included studies evaluated the effectiveness of the interventions, and small effects were observed on PA and SB. Possible reasons for the small effect sizes may have included inappropriate design (nonrandom allocation) [89], lack of exposure to automated intervention because of technical problems [89], use of nonpersonalized behavioral interventions [94], lack of participant engagement with the intervention [87], and insufficient inclusion of behavior change techniques [96]. Moreover, a binary sign test conducted in this review attempts to provide additional information and contribute to transparency in interpreting the effect direction. However, this should be interpreted carefully, as the small number of studies may have underpowered the test.

Most of the studies included in the review focused on PA, whereas only a few targeted SB; none assessed standing as a distinct outcome. Moreover, most smartphone-based SB and 
PA interventions used built-in smartphone accelerometers and sensors as a tool to capture individual behaviors to inform behavioral interventions (ie, step counts were used to help participants set goals and monitor progress or provide activity suggestions) [87,94-96].

The benefits of smartphone interventions include the ability to collect and measure contextual factors (eg, location, weather, and emotional or psychological states), which could be used to personalize behavior interventions [99]. Existing research evidence has shown that contextually aware reminders increase the effectiveness of mHealth PA interventions [21,100]. Furthermore, leveraging contextual information in PA interventions enables the triggering of more frequent reminders without annoying the individual receiving the reminder, and these types of interventions are considered more acceptable [100]. Despite these proposed benefits, most of the included studies lacked an assessment of contextual factors. A likely reason for the lack of contextual factors in the reviewed studies is the technical challenges, such as system requirements. For example, high battery consumption and low localization speed by a built-in smartphone GPS compromise mobile app performance [101]. Another important reason might be the privacy implications for smartphone users [102]. Privacy breaches are most probable when context-sensitive information such as location is monitored [103]. Moreover, people generally refuse to be monitored for where they go or what they do [104]. A limitation of using native smartphone sensors is that they do not provide research-grade precision for measuring PA and SB. Commonly used accelerometers (eg, built-in smartphone accelerometers and Actigraph GT3X) measure SB by focusing on periods where the device records activity counts below a certain cutoff point, such as less than 100 counts per minute [105]. This leads to the miscategorization of SB [106]. Although postural devices (inclinometers) such as activPAL have excellent accuracy in measuring SB [107], they require proprietary software (activPAL Professional Research Edition, PAL Technologies) to process and collect the data and thus have low utility for real-time interventions. Finally, as highlighted above, none of the included studies assessed standing as an outcome, despite 3 studies promoting standing in their intervention messages $[87,94,95]$. This might be explained by the inability to measure standing in real time for a dynamic intervention purpose and limited evidence advocating standing as a distinct activity that brings health benefits. However, short-term and small-scale studies that support standing are emerging. In a lab-based study, breaking up every 30 minutes of sitting by 5 minutes of standing was shown to reduce postprandial blood glucose (34\% reduction) compared with prolonged sitting in postmenopausal women [108]. Moreover, an office-based study has shown that an afternoon of standing reduced postprandial glucose (43\% reduction) compared with sitting while performing computer work [109].

The included interventions comprised pre-post, RCT, and 3-arm quasi-experimental designs. These commonly used experimental designs are unable to assess rich context and time-intensive data. For example, RCTs do not provide information on the particular time when the intervention had an effect and the moderators that affected the behavior change [110]. In fact,
RCTs typically consider the overall impact of an intervention package on behavior or health outcomes, not specific components of that intervention. Other study designs, such as factorial designs, are capable of investigating the effects of each intervention component and the interactions between components and the dosing of the intervention. However, they are not sufficient to delineate when the intervention was most effective and what moderators influenced the intervention [110]. A microrandomized trial may address these design limitations. The microrandomized trial is a novel experimental design to determine the optimal delivery of just-in-time adaptive interventions [110]. A key advantage is that microrandomized trials not only assess the effect of specific intervention components but also changes in effects over time and moderators, including contextual and psychological factors [110]. Microrandomization can help elucidate potential causal relationships between each randomized intervention feature and proximal effects (what happens in a limited time window, for example within 1 hour, following a randomized intervention) and allow assessment of time-varying contextual and psychological factors moderating those proximal effects [110].

Most of the included studies lacked comprehensive incorporation and testing of behavior change techniques, although they were theory-based. The precise specification of behavior change techniques-which are active ingredients of behavior change interventions and specification of intervention features of PA (eg, mode of delivery and frequency) - help provide accumulative evidence for effective and replicable interventions [111]. Smartphone-based interventions undertaking dynamic approaches with a proper experimental design (ie, microrandomized), while testing various behavior change techniques, are expected to provide more robust evidence than traditional theory approaches.

\section{Limitations and Strengths}

A limitation of this review is the heterogeneity in the reported effectiveness data that prevented a pooled meta-analysis. Other limitations include the small sample size and short duration of the included interventions and nonrandomized study designs. Moreover, women exceeded men in most studies, and all studies involved adult populations, which might limit the generalizability of the findings. A key strength of this review is that it focuses on the integration of dynamic models in smartphone-based PA and SB studies, as such dynamic models fit best with mobile technologies. Another strength is the use of the effect direction plot to present the direction of the effectiveness results. This methodology is superior to narrative synthesis, as it helps with the overall interpretation of the findings. Future studies, in the context of SB and PA behaviors, are suggested to incorporate and assess the effect of relevant environmental and internal contextual moderators, use computational models, and investigate $\mathrm{SB}$, in particular, as there is a significant evidence gap.

\section{Conclusions}

In conclusion, despite the recommendation for integrating dynamic models such as control systems to better harness the potential of mobile technologies, this review showed that few studies have actually adopted this approach to promote PA and 
reduce SB. To some extent, this research gap may be because of the complex and multifaceted nature of dynamic models, such as control systems, in integrating adaptive contexts and real-time measurement of outcomes.

\section{Acknowledgments}

The authors would like to thank Rachel West (Liaison Librarian at Deakin University) and Dr Gavin Abbott (Senior Research Fellow and Biostatistician at Deakin University) for their guidance. RDK received a Deakin University Postgraduate Research Scholarship for his $\mathrm{PhD}$.

\section{Authors' Contributions}

RDK, RM, and SMSI designed the study. RDK conducted the search and removed duplicates; RDK and JM screened the titles, abstracts, and full text of the studies and extracted data; and RDK drafted the systematic review manuscript. RM, SMSI, DWD, and MA contributed to verifying screening; all coauthors-SMSI, DWD, JM, MA, and RM-contributed to the critical revision of the manuscript and approved the final manuscript.

\section{Conflicts of Interest}

None declared.

\section{Multimedia Appendix 1}

Search strategy.

[DOCX File, 13 KB-Multimedia Appendix 1]

\section{Multimedia Appendix 2}

Reason for exclusion.

[DOCX File, 16 KB-Multimedia Appendix 2]

\section{Multimedia Appendix 3}

Quality assessment.

[DOCX File, 15 KB-Multimedia Appendix 3]

\section{References}

1. Taj F, Klein MC, van Halteren A. Digital health behavior change technology: bibliometric and scoping review of two decades of research. JMIR Mhealth Uhealth 2019 Dec 13;7(12):e13311 [FREE Full text] [doi: 10.2196/13311] [Medline: 31833836]

2. Schoeppe S, Alley S, Van Lippevelde W, Bray NA, Williams SL, Duncan MJ, et al. Efficacy of interventions that use apps to improve diet, physical activity and sedentary behaviour: a systematic review. Int J Behav Nutr Phys Act 2016 Dec 07;13(1):127 [FREE Full text] [doi: 10.1186/s12966-016-0454-y] [Medline: 27927218]

3. Direito A, Carraça E, Rawstorn J, Whittaker R, Maddison R. mHealth technologies to influence physical activity and sedentary behaviors: behavior change techniques, systematic review and meta-analysis of randomized controlled trials. Ann Behav Med 2017 Apr 18;51(2):226-239. [doi: 10.1007/s12160-016-9846-0] [Medline: 27757789]

4. Riley WT, Rivera DE, Atienza AA, Nilsen W, Allison SM, Mermelstein R. Health behavior models in the age of mobile interventions: are our theories up to the task? Transl Behav Med 2011 Mar 24;1(1):53-71 [FREE Full text] [doi:

10.1007/s13142-011-0021-7] [Medline: 21796270]

5. Michie S, Abraham C. Interventions to change health behaviours: evidence-based or evidence-inspired? Psychol Health 2004 Feb;19(1):29-49. [doi: 10.1080/0887044031000141199]

6. Salwen-Deremer JK, Khan AS, Martin SS, Holloway BM, Coughlin JW. Incorporating health behavior theory into mHealth: an examination of weight loss, dietary, and physical activity interventions. J Technol Behav Sci 2019 Nov 04;5(1):51-60. [doi: 10.1007/s41347-019-00118-6]

7. Intille S, Kukla C, Farzanfar R, Bakr W. Just-in-time technology to encourage incremental, dietary behavior change. AMIA Annu Symp Proc 2003:874 [FREE Full text] [Medline: 14728379]

8. Spruijt-Metz D, Wen CK, O'Reilly G, Li M, Lee S, Emken BA, et al. Innovations in the use of interactive technology to support weight management. Curr Obes Rep 2015 Dec 12;4(4):510-519 [FREE Full text] [doi: 10.1007/s13679-015-0183-6] [Medline: 26364308]

9. Spruijt-Metz D, Nilsen W. Dynamic models of behavior for just-in-time adaptive interventions. IEEE Pervasive Comput 2014 Jul;13(3):13-17. [doi: 10.1109/mprv.2014.46]

10. Carver CS, Scheier MF. Control theory: a useful conceptual framework for personality-social, clinical, and health psychology. Psychol Bullet 1982;92(1):111-135. [doi: 10.1037/0033-2909.92.1.111] 
11. Rivera DE, Pew MD, Collins LM. Using engineering control principles to inform the design of adaptive interventions: a conceptual introduction. Drug Alcohol Depend 2007 May;88 Suppl 2:31-40 [FREE Full text] [doi: 10.1016/j.drugalcdep.2006.10.020] [Medline: $\underline{17169503]}$

12. Conroy DE, Hojjatinia S, Lagoa CM, Yang C, Lanza ST, Smyth JM. Personalized models of physical activity responses to text message micro-interventions: a proof-of-concept application of control systems engineering methods. Psychol Sport Exerc 2019 Mar;41:172-180 [FREE Full text] [doi: 10.1016/j.psychsport.2018.06.011] [Medline: $\underline{30853855]}$

13. Moher D, Liberati A, Tetzlaff J, Altman DG, PRISMA Group. Preferred reporting items for systematic reviews and meta-analyses: the PRISMA statement. PLoS Med 2009 Jul 21;6(7):e1000097 [FREE Full text] [doi: 10.1371/journal.pmed.1000097] [Medline: 19621072]

14. Daryabeygi-Khotbehsara R. Systematic review of smartphone-based interventions to reduce sedentary behaviour and promote physical activity using dynamic models. National Institute for Health Research. 2013. URL: https://www. crd.york.ac.uk/PROSPERO/display record.php?RecordID=139350 [accessed 2020-01-22]

15. Higgins J, Altman DG, Gøtzsche PC, Jüni P, Moher D, Oxman AD, Cochrane Bias Methods Group, Cochrane Statistical Methods Group. The Cochrane Collaboration's tool for assessing risk of bias in randomised trials. Br Med J 2011 Oct 18;343:d5928. [doi: 10.1136/bmj.d5928] [Medline: 22008217]

16. Tufanaru C, Munn Z, Aromataris E, Campbell J, Hopp L. Chapter 3: Systematic reviews of effectiveness. In: Aromataris E, Munn Z, editors. JBI Manual for Evidence Synthesis. University of Adelaide, South Australia: The Joanna Briggs Institute; 2020.

17. McKenzie JE, Brennan SE. Synthesizing and presenting findings using other methods. In: Cochrane Handbook for Systematic Reviews of Interventions. London: John Wiley \& Sons Ltd; Sep 20, 2019:321-347.

18. Thomson HJ, Thomas S. The effect direction plot: visual display of non-standardised effects across multiple outcome domains. Res Synth Methods 2013 Mar 12;4(1):95-101 [FREE Full text] [doi: 10.1002/jrsm.1060] [Medline: 23795209]

19. Campbell M, McKenzie JE, Sowden A, Katikireddi SV, Brennan SE, Ellis S, et al. Synthesis without meta-analysis (SWiM) in systematic reviews: reporting guideline. Br Med J 2020 Jan 16;368:16890 [FREE Full text] [doi: 10.1136/bmj.16890] [Medline: 31948937]

20. Boon MH, Thomson H. The effect direction plot revisited: Application of the 2019 Cochrane Handbook guidance on alternative synthesis methods. Res Synth Methods 2021 Jan 05;12(1):29-33 [FREE Full text] [doi: 10.1002/jrsm.1458] [Medline: 32979023]

21. Klasnja P, Smith S, Seewald NJ, Lee A, Hall K, Luers B, et al. Efficacy of contextually tailored suggestions for physical activity: a micro-randomized optimization trial of HeartSteps. Ann Behav Med 2019 May 03;53(6):573-582 [FREE Full text] [doi: 10.1093/abm/kay067] [Medline: 30192907]

22. Martín CA, Rivera DE, Hekler EB, Riley WT, Buman MP, Adams MA, et al. Development of a control-oriented model of social cognitive theory for optimized mhealth behavioral interventions. IEEE Trans Control Syst Technol 2020 Mar;28(2):331-346 [FREE Full text] [doi: 10.1109/tcst.2018.2873538] [Medline: 33746479]

23. Adams MA, Sallis JF, Norman GJ, Hovell MF, Hekler EB, Perata E. An adaptive physical activity intervention for overweight adults: a randomized controlled trial. PLoS One 2013;8(12):e82901 [FREE Full text] [doi: 10.1371/journal.pone.0082901] [Medline: 24349392]

24. Bickmore TW, Schulman D, Sidner CL. A reusable framework for health counseling dialogue systems based on a behavioral medicine ontology. J Biomed Inform 2011 Apr;44(2):183-197 [FREE Full text] [doi: 10.1016/j.jbi.2010.12.006] [Medline: 21220044]

25. Hurling R, Catt M, Boni MD, Fairley BW, Hurst T, Murray P, et al. Using internet and mobile phone technology to deliver an automated physical activity program: randomized controlled trial. J Med Internet Res 2007 Apr 27;9(2):e7 [FREE Full text] [doi: 10.2196/jmir.9.2.e7] [Medline: 17478409 ]

26. Fukuoka Y, Kamitani E, Bonnet K, Lindgren T. Real-time social support through a mobile virtual community to improve healthy behavior in overweight and sedentary adults: a focus group analysis. J Med Internet Res 2011 Jul 14;13(3):e49 [FREE Full text] [doi: 10.2196/jmir.1770] [Medline: 21752785]

27. Hughes DC, Andrew A, Denning T, Hurvitz P, Lester J, Beresford S, et al. BALANCE (Bioengineering Approaches for Lifestyle Activity and Nutrition Continuous Engagement): developing new technology for monitoring energy balance in real time. J Diabetes Sci Technol 2010 Mar 01;4(2):429-434 [FREE Full text] [doi: 10.1177/193229681000400224] [Medline: 20307404]

28. Liao P, Dempsey W, Sarker H, Hossain SM, Al'absi M, Klasnja P, et al. Just-in-time but not too much: determining treatment timing in mobile health. Proc ACM Interact Mob Wearable Ubiquitous Technol 2018 Dec;2(4):179 [FREE Full text] [doi: 10.1145/3287057] [Medline: $\underline{30801052]}$

29. Pirolli P, Youngblood GM, Du H, Konrad A, Nelson L, Springer A. Scaffolding the mastery of healthy behaviors with fittle+ systems: evidence-based interventions and theory. Hum Comp Interact 2018 Oct 15;36(2):73-106. [doi: $10.1080 / 07370024.2018 .1512414]$

30. Yang P, Stankevicius D, Marozas V, Deng Z, Liu E, Lukosevicius A, et al. Lifelogging data validation model for internet of things enabled personalized healthcare. IEEE Trans Syst Man Cybern Syst 2018 Jan;48(1):50-64. [doi:

10.1109/tsmc.2016.2586075] 
31. Stroulia E, Fairbairn S, Bazelli B, Gibbs D, Lederer R, Faulkner R, et al. Smart-phone application design for lasting behavioral changes. In: Proceedings of the 26th IEEE International Symposium on Computer-Based Medical Systems. 2013 Presented at: 26th IEEE International Symposium on Computer-Based Medical Systems; June 20-22, 2013; Porto, Portugal. [doi: 10.1109/CBMS.2013.6627804]

32. Naved MM, Uddin MY. Adaptive notifications generation for smartphone users based on their physical activities. In: Proceedings of the 5th International Conference on Networking, Systems and Security (NSysS). 2018 Presented at: 5th International Conference on Networking, Systems and Security (NSysS); Dec. 18-20, 2018; Dhaka, Bangladesh. [doi: 10.1109/NSysS.2018.8631366]

33. Zheng H, Nugent C, McCullagh P, Huang Y, Zhang S, Burns W, et al. Smart self management: assistive technology to support people with chronic disease. J Telemed Telecare 2010;16(4):224-227. [doi: 10.1258/jtt.2010.004017] [Medline: $\underline{20511581]}$

34. Pirolli P. A computational cognitive model of self-efficacy and daily adherence in mHealth. Transl Behav Med 2016 Dec;6(4):496-508 [FREE Full text] [doi: 10.1007/s13142-016-0391-y] [Medline: 27848213]

35. Zhao ZW, Ma Q, Li CC, Liu L, Li WD. A machine-to-machine based framework for diabetes lifestyle management. In: Proceedings of the 10th IEEEE International Conference on Networking, Sensing and Control (ICNSC). 2013 Presented at: 10th IEEEE International Conference on Networking, Sensing and Control (ICNSC); April 10-12, 2013; Evry, France. [doi: 10.1109/ICNSC.2013.6548800]

36. Huang CY, Yang MC, Huang CY, Chen YJ, Wu ML, Chen KW. A chatbot-supported smart wireless interactive healthcare system for weight control and health promotion. In: Proceedings of the IEEE International Conference on Industrial Engineering and Engineering Management (IEEM). 2018 Presented at: IEEE International Conference on Industrial Engineering and Engineering Management (IEEM); Dec. 16-19, 2018; Bangkok, Thailand. [doi: 10.1109/IEEM.2018.8607399]

37. Müller AM, Blandford A, Yardley L. The conceptualization of a Just-In-Time Adaptive Intervention (JITAI) for the reduction of sedentary behavior in older adults. Mhealth 2017;3:37 [FREE Full text] [doi: 10.21037/mhealth.2017.08.05] [Medline: 29184889]

38. Mohadis HM, Mohamad Ali N. Designing persuasive application to encourage physical activity at workplace among older workers. In: Proceedings of the Sixth International Conference on Digital Information and Communication Technology and its Applications (DICTAP).: July 21-23, 2016; 2016 Presented at: Konya, Turkey; Konya, Turkey; Sixth International Conference on Digital Information and Communication Technology and its Applications (DICTAP) p. 1102-1114. [doi: 10.1109/DICTAP.2016.7544013]

39. Boulton E, Hawley-Hague H, French DP, Mellone S, Zacchi A, Clemson L, et al. Implementing behaviour change theory and techniques to increase physical activity and prevent functional decline among adults aged 61-70: The PreventIT project. Prog Cardiovasc Dis 2019;62(2):147-156 [FREE Full text] [doi: 10.1016/j.pcad.2019.01.003] [Medline: $\underline{\text { 30685469] }}$

40. Martin SS, Feldman DI, Blumenthal RS, Jones SR, Post WS, McKibben RA, et al. mActive: A randomized clinical trial of an automated mhealth intervention for physical activity promotion. J Am Heart Assoc 2015 Nov 09;4(11):e002239 [FREE Full text] [doi: 10.1161/JAHA.115.002239] [Medline: 26553211]

41. Buman MP, Epstein DR, Gutierrez M, Herb C, Hollingshead K, Huberty JL, et al. BeWell24: development and process evaluation of a smartphone "app" to improve sleep, sedentary, and active behaviors in US Veterans with increased metabolic risk. Transl Behav Med 2016 Sep;6(3):438-448 [FREE Full text] [doi: 10.1007/s13142-015-0359-3] [Medline: 27528532]

42. Lim S, Kang SM, Kim KM, Moon JH, Choi SH, Hwang H, et al. Multifactorial intervention in diabetes care using real-time monitoring and tailored feedback in type 2 diabetes. Acta Diabetol 2016 Apr;53(2):189-198. [doi: 10.1007/s00592-015-0754-8] [Medline: 25936739]

43. Rawstorn J, Gant N, Meads A, Warren I, Maddison R. Remotely delivered exercise-based cardiac rehabilitation: design and content development of a novel mHealth platform. JMIR Mhealth Uhealth 2016 Jun 24;4(2):e57 [FREE Full text] [doi: 10.2196/mhealth.5501] [Medline: 27342791]

44. Vankipuram M, McMahon S, Fleury J. ReadySteady: app for accelerometer-based activity monitoring and wellness-motivation feedback system for older adults. AMIA Annu Symp Proc 2012;2012:931-939 [FREE Full text] [Medline: 23304368]

45. Martin CK, Gilmore LA, Apolzan JW, Myers CA, Thomas DM, Redman LM. Smartloss: A personalized mobile health intervention for weight management and health promotion. JMIR Mhealth Uhealth 2016 Mar 16;4(1):e18 [FREE Full text] [doi: 10.2196/mhealth.5027] [Medline: 26983937]

46. Ryan P, Papanek P, Csuka ME, Brown ME, Hopkins S, Lynch S, Striving to be Strong Team. Background and method of the Striving to be Strong study a RCT testing the efficacy of a m-health self-management intervention. Contemp Clin Trials 2018 Aug;71:80-87. [doi: 10.1016/j.cct.2018.06.006] [Medline: 29894865]

47. Clark DO, Srinivas P, Bodke K, Keith N, Hood S, Tu W. Addressing people and place microenvironments in weight loss disparities (APP-Me): Design of a randomized controlled trial testing timely messages for weight loss behavior in low income Black and White Women. Contemp Clin Trials 2018 Apr;67:74-80 [FREE Full text] [doi: 10.1016/j.cct.2018.01.006] [Medline: 29357313] 
48. Thomas JG, Bond DS. Behavioral response to a just-in-time adaptive intervention (JITAI) to reduce sedentary behavior in obese adults: implications for JITAI optimization. Health Psychol 2015 Dec;34S:1261-1267 [FREE Full text] [doi: 10.1037/hea0000304] [Medline: 26651467]

49. Marquet O, Alberico C, Hipp A. Pokémon GO and physical activity among college students. A study using ecological momentary assessment. Comp Hum Behav 2018 Apr;81:215-222. [doi: 10.1016/j.chb.2017.12.028]

50. Srinivas P, Bodke K, Ofner S, Keith NR, Tu W, Clark DO. Context-sensitive ecological momentary assessment: application of user-centered design for improving user satisfaction and engagement during self-report. JMIR Mhealth Uhealth 2019 Apr 03;7(4):e10894 [FREE Full text] [doi: 10.2196/10894] [Medline: 30942698]

51. Cruciani F, Nugent C, Cleland I, McCullagh P. Rich context information for just-in-time adaptive intervention promoting physical activity. In: 39th Annual International Conference of the IEEE Engineering in Medicine and Biology Society (EMBC). 2017 Presented at: 39th Annual International Conference of the IEEE Engineering in Medicine and Biology Society (EMBC); July 11-15, 2017; Jeju, Korea (South). [doi: 10.1109/EMBC.2017.8036957]

52. Dunton GF, Dzubur E, Intille S. Feasibility and performance test of a real-time sensor-informed context-sensitive ecological momentary assessment to capture physical activity. J Med Internet Res 2016 Jun 01;18(6):e106 [FREE Full text] [doi: 10.2196/jmir.5398] [Medline: 27251313]

53. Dunton GF, Dzubur E, Kawabata K, Yanez B, Bo B, Intille S. Development of a smartphone application to measure physical activity using sensor-assisted self-report. Front Public Health 2014;2:12 [FREE Full text] [doi: 10.3389/fpubh.2014.00012] [Medline: 24616888]

54. Dunton GF, Liao Y, Kawabata K, Intille S. Momentary assessment of adults' physical activity and sedentary behavior: feasibility and validity. Front Psychol 2012;3:260 [FREE Full text] [doi: 10.3389/fpsyg.2012.00260] [Medline: 22866046]

55. Rofey DL, Hull EE, Phillips J, Vogt K, Silk JS, Dahl RE. Utilizing Ecological Momentary Assessment in pediatric obesity to quantify behavior, emotion, and sleep. Obesity (Silver Spring) 2010 Jun;18(6):1270-1272 [FREE Full text] [doi: 10.1038/oby.2009.483] [Medline: 20019675]

56. Smith A, de Salas K, Lewis I, Schüz B. Developing smartphone apps for behavioural studies: The AlcoRisk app case study. J Biomed Inform 2017 Aug;72:108-119 [FREE Full text] [doi: 10.1016/j.jbi.2017.07.007] [Medline: 28709856]

57. Jones KK, Zenk SN, McDonald A, Corte C. Experiences of African-American women with smartphone-based ecological momentary assessment. Public Health Nurs 2016 Jul;33(4):371-380. [doi: 10.1111/phn.12239] [Medline: 26530781]

58. Li Z, Das S, Codella JW, Hao T, Lin K, Maduri C, et al. An adaptive, data-driven personalized advisor for increasing physical activity. IEEE J Biomed Health Inform 2019 May;23(3):999-1010. [doi: 10.1109/JBHI.2018.2879805] [Medline: 30418890]

59. Fahim M, Baker T, Khattak AM, Shah B, Aleem S, Chow F. Context mining of sedentary behaviour for promoting self-awareness using a smartphone. Sensors (Basel) 2018 Mar 15;18(3):874 [FREE Full text] [doi: 10.3390/s18030874] [Medline: 29543763]

60. Brannon EE, Cushing CC, Crick CJ, Mitchell TB. The promise of wearable sensors and ecological momentary assessment measures for dynamical systems modeling in adolescents: a feasibility and acceptability study. Transl Behav Med 2016 Dec;6(4):558-565 [FREE Full text] [doi: 10.1007/s13142-016-0442-4] [Medline: 27678501]

61. Valentiner LS, Thorsen IK, Kongstad MB, Brinkløv CF, Larsen RT, Karstoft K, et al. Effect of ecological momentary assessment, goal-setting and personalized phone-calls on adherence to interval walking training using the InterWalk application among patients with type 2 diabetes-A pilot randomized controlled trial. PLoS One 2019;14(1):e0208181 [FREE Full text] [doi: 10.1371/journal.pone.0208181] [Medline: $\underline{30629601]}$

62. Alian S, Li J, Pandey V. A personalized recommendation system to support diabetes self-management for American Indians. IEEE Access 2018;6:73041-73051. [doi: 10.1109/ACCESS.2018.2882138]

63. Hales S, Turner-McGrievy GM, Wilcox S, Fahim A, Davis R, Huhns M, et al. Social networks for improving healthy weight loss behaviors for overweight and obese adults: a randomized clinical trial of the social pounds off digitally (Social POD) mobile app. Int J Med Inform 2016 Oct;94:81-90. [doi: 10.1016/j.ijmedinf.2016.07.003] [Medline: 27573315]

64. Salvi D, Ottaviano M, Muuraiskangas S, Martínez-Romero A, Vera-Muñoz C, Triantafyllidis A, et al. An m-Health system for education and motivation in cardiac rehabilitation: the experience of HeartCycle guided exercise. J Telemed Telecare 2018 May;24(4):303-316. [doi: 10.1177/1357633X17697501] [Medline: 28350282]

65. Tabak M, op den Akker H, Hermens H. Motivational cues as real-time feedback for changing daily activity behavior of patients with COPD. Patient Educ Couns 2014 Mar;94(3):372-378. [doi: 10.1016/j.pec.2013.10.014] [Medline: 24332934]

66. Maddison R, Rawstorn JC, Stewart RA, Benatar J, Whittaker R, Rolleston A, et al. Effects and costs of real-time cardiac telerehabilitation: randomised controlled non-inferiority trial. Heart 2019 Jan;105(2):122-129 [FREE Full text] [doi: 10.1136/heartjnl-2018-313189] [Medline: $\underline{\text { 30150328] }}$

67. Kramer JN, Künzler F, Mishra V, Presset B, Kotz D, Smith S, et al. Investigating intervention components and exploring states of receptivity for a smartphone app to promote physical activity: protocol of a microrandomized trial. JMIR Res Protoc 2019 Jan 31;8(1):e11540 [FREE Full text] [doi: 10.2196/11540] [Medline: 30702430]

68. Militello L, Melnyk BM, Hekler EB, Small L, Jacobson D. Automated behavioral text messaging and face-to-face intervention for parents of overweight or obese preschool children: results from a pilot study. JMIR Mhealth Uhealth 2016 Mar 14;4(1):e21 [FREE Full text] [doi: 10.2196/mhealth.4398] [Medline: 26976387] 
69. Brakenridge CL, Healy GN, Winkler EA, Fjeldsoe BS. Usage, acceptability, and effectiveness of an activity tracker in a randomized trial of a workplace sitting intervention: mixed-methods evaluation. Interact J Med Res 2018 Mar 02;7(1):e5 [FREE Full text] [doi: 10.2196/ijmr.9001] [Medline: 29500158]

70. Yom-Tov E, Feraru G, Kozdoba M, Mannor S, Tennenholtz M, Hochberg I. Encouraging physical activity in patients with diabetes: intervention using a reinforcement learning system. J Med Internet Res 2017 Oct 10;19(10):e338 [FREE Full text] [doi: 10.2196/jmir.7994] [Medline: 29017988]

71. Lin PH, Intille S, Bennett G, Bosworth HB, Corsino L, Voils C, et al. Adaptive intervention design in mobile health: Intervention design and development in the Cell Phone Intervention for You trial. Clin Trials 2015 Dec;12(6):634-645 [FREE Full text] [doi: 10.1177/1740774515597222] [Medline: 26229119]

72. Alexander B, Karakas K, Kohout C, Sakarya H, Singh N, Stachtiaris J, et al. A behavioral sensing system that promotes positive lifestyle changes and improves metabolic control among adults with type 2 diabetes. In: Proceedings of the Systems and Information Engineering Design Symposium (SIEDS). 2017 Presented at: Systems and Information Engineering Design Symposium (SIEDS); April 28-28, 2017; Charlottesville, VA, USA. [doi: 10.1109/SIEDS.2017.7937732]

73. Al-Ozairi E, Ridge K, Taghadom E, de Zoysa N, Tucker C, Stewart K, et al. Diabetes and TelecommunicationS (DATES) study to support self-management for people with type 2 diabetes: a randomized controlled trial. BMC Public Health 2018 Nov 12;18(1):1249 [FREE Full text] [doi: 10.1186/s12889-018-6136-8] [Medline: 30419893]

74. Baert A, Clays E, Bolliger L, De Smedt D, Lustrek M, Vodopija A, et al. A Personal Decision Support System for Heart Failure Management (HeartMan): study protocol of the HeartMan randomized controlled trial. BMC Cardiovasc Disord 2018 Sep 27;18(1):186. [doi: 10.1186/s12872-018-0921-2]

75. Bardus M, Hamadeh G, Hayek B, Al Kherfan R. A self-directed mobile intervention (WaznApp) to promote weight control among employees at a Lebanese University: protocol for a feasibility pilot randomized controlled trial. JMIR Res Protoc 2018 May 16;7(5):e133 [FREE Full text] [doi: 10.2196/resprot.9793] [Medline: 29769174]

76. Evans EH, Araújo-Soares V, Adamson A, Batterham AM, Brown H, Campbell M, et al. The NULevel trial of a scalable, technology-assisted weight loss maintenance intervention for obese adults after clinically significant weight loss: study protocol for a randomised controlled trial. Trials 2015 Sep 22;16:421 [FREE Full text] [doi: 10.1186/s13063-015-0931-7] [Medline: 26395774]

77. Goldstein SP, Thomas JG, Vithiananthan S, Blackburn GA, Jones DB, Webster J, et al. Multi-sensor ecological momentary assessment of behavioral and psychosocial predictors of weight loss following bariatric surgery: study protocol for a multicenter prospective longitudinal evaluation. BMC Obes 2018;5:27 [FREE Full text] [doi: 10.1186/s40608-018-0204-6] [Medline: 30410772]

78. Hassoon A, Schrack J, Naiman D, Lansey D, Baig Y, Stearns V, et al. Increasing physical activity amongst overweight and obese cancer survivors using an alexa-based intelligent agent for patient coaching: protocol for the Physical Activity by Technology Help (PATH) trial. JMIR Res Protoc 2018 Feb 12;7(2):e27 [FREE Full text] [doi: 10.2196/resprot.9096] [Medline: 29434016]

79. Hurley JC, Hollingshead KE, Todd M, Jarrett CL, Tucker WJ, Angadi SS, et al. The Walking Interventions Through Texting (WalkIT) Trial: Rationale, design, and protocol for a factorial randomized controlled trial of adaptive interventions for overweight and obese, inactive adults. JMIR Res Protoc 2015 Sep 11;4(3):e108 [FREE Full text] [doi: 10.2196/resprot.4856] [Medline: 26362511]

80. Orme MW, Weedon AE, Esliger DW, Saukko PM, Morgan MD, Steiner MC, et al. Study protocol for Chronic Obstructive Pulmonary Disease-Sitting and ExacerbAtions Trial (COPD-SEAT): a randomised controlled feasibility trial of a home-based self-monitoring sedentary behaviour intervention. BMJ Open 2016 Oct 03;6(10):e013014 [FREE Full text] [doi: 10.1136/bmjopen-2016-013014] [Medline: 27697880]

81. Pellegrini CA, Hoffman SA, Collins LM, Spring B. Optimization of remotely delivered intensive lifestyle treatment for obesity using the Multiphase Optimization Strategy: Opt-IN study protocol. Contemp Clin Trials 2014 Jul;38(2):251-259 [FREE Full text] [doi: 10.1016/j.cct.2014.05.007] [Medline: 24846621]

82. Phillips SM, Collins LM, Penedo FJ, Courneya KS, Welch W, Cottrell A, et al. Optimization of a technology-supported physical activity intervention for breast cancer survivors: Fit2Thrive study protocol. Contemp Clin Trials 2018 Mar;66:9-19 [FREE Full text] [doi: 10.1016/j.cct.2018.01.001] [Medline: 29330081]

83. Downs DS, Savage JS, Rivera DE, Smyth JM, Rolls BJ, Hohman EE, et al. Individually tailored, adaptive intervention to manage gestational weight gain: protocol for a randomized controlled trial in women with overweight and obesity. JMIR Res Protoc 2018 Jun 08;7(6):e150 [FREE Full text] [doi: 10.2196/resprot.9220] [Medline: 29884603]

84. Vidmar AP, Salvy SJ, Pretlow R, Mittelman SD, Wee C, Fink C, et al. An addiction-based mobile health weight loss intervention: protocol of a randomized controlled trial. Contemp Clin Trials 2019 Mar;78:11-19 [FREE Full text] [doi: 10.1016/j.cct.2019.01.008] [Medline: $\underline{30654026}$ ]

85. Block G, Azar KM, Romanelli RJ, Block TJ, Hopkins D, Carpenter HA, et al. Diabetes prevention and weight loss with a fully automated behavioral intervention by email, web, and mobile phone: a randomized controlled trial among persons with prediabetes. J Med Internet Res 2015 Oct 23;17(10):e240 [FREE Full text] [doi: 10.2196/jmir.4897] [Medline: 26499966] 
86. Baretta D, Sartori F, Greco A, D’Addario M, Melen R, Steca P. Improving physical activity mhealth interventions: development of a computational model of self-efficacy theory to define adaptive goals for exercise promotion. Adv Hum Comp Interact 2019 Mar 04;2019:1-11. [doi: 10.1155/2019/3068748]

87. Direito A, Tooley M, Hinbarji M, Albatal R, Jiang Y, Whittaker R, et al. Tailored daily activity: an adaptive physical activity smartphone intervention. Telemed J E Health 2020 Apr 01;26(4):426-437. [doi: 10.1089/tmj.2019.0034] [Medline: 31063038]

88. Direito A, Walsh D, Hinbarji M, Albatal R, Tooley M, Whittaker R, et al. Using the intervention mapping and behavioral intervention technology frameworks: development of an mhealth intervention for physical activity and sedentary behavior change. Health Educ Behav 2018 Jun 07;45(3):331-348. [doi: 10.1177/1090198117742438] [Medline: 29216765]

89. Middelweerd A, Mollee J, Klein MM, Manzoor A, Brug J, Te Velde SJ. The use and effects of an app-based physical activity intervention "Active2Gether" in young adults: quasi-experimental trial. JMIR Form Res 2020 Jan 21;4(1):e12538 [FREE Full text] [doi: 10.2196/12538] [Medline: $\underline{\text { 31961330] }}$

90. Klein M, Manzoor A, Mollee J. Active2Gether: A personalized m-health intervention to encourage physical activity. Sensors (Basel) 2017 Jun 19;17(6):1436 [FREE Full text] [doi: 10.3390/s17061436] [Medline: 28629178]

91. Middelweerd A, Te Velde SJ, Mollee JS, Klein MC, Brug J. App-based intervention combining evidence-based behavior change techniques with a model-based reasoning system to promote physical activity among young adults (Active2Gether): descriptive study of the development and content. JMIR Res Protoc 2018 Dec 21;7(12):e185 [FREE Full text] [doi: 10.2196/resprot.7169] [Medline: $\underline{30578198]}$

92. Korinek EV, Phatak SS, Martin CA, Freigoun MT, Rivera DE, Adams MA, et al. Adaptive step goals and rewards: a longitudinal growth model of daily steps for a smartphone-based walking intervention. J Behav Med 2018 Feb 16;41(1):74-86. [doi: 10.1007/s10865-017-9878-3] [Medline: 28918547]

93. Freigoun M, Martin C, Magann A, Rivera DE, Phatak S, Korinek E, et al. System identification of Just Walk: A behavioral mHealth intervention for promoting physical activity. In: Proceedings of the American Control Conference (ACC). 2017 May 24 Presented at: American Control Conference (ACC); May 24-26, 2017; Seattle, WA, USA. [doi: 10.23919/acc.2017.7962940]

94. Rabbi M, Pfammatter A, Zhang M, Spring B, Choudhury T. Automated personalized feedback for physical activity and dietary behavior change with mobile phones: a randomized controlled trial on adults. JMIR Mhealth Uhealth 2015 May 14;3(2):e42 [FREE Full text] [doi: 10.2196/mhealth.4160] [Medline: 25977197]

95. Rabbi M, Aung MS, Gay G, Reid MC, Choudhury T. Feasibility and acceptability of mobile phone-based auto-personalized physical activity recommendations for chronic pain self-management: pilot study on adults. J Med Internet Res 2018 Oct 26;20(10):e10147 [FREE Full text] [doi: 10.2196/10147] [Medline: 30368433]

96. Zhou M, Fukuoka Y, Mintz Y, Goldberg K, Kaminsky P, Flowers E, et al. Evaluating machine learning-based automated personalized daily step goals delivered through a mobile phone app: randomized controlled trial. JMIR Mhealth Uhealth 2018 Jan 25;6(1):e28 [FREE Full text] [doi: 10.2196/mhealth.9117] [Medline: 29371177]

97. Ghahramani Z. Learning dynamic Bayesian networks. In: Adaptive Processing of Sequences and Data Structures. Berlin, Heidelberg: Springer; 1998.

98. Riley W, Cesar A, Martin CA, Rivera DE. The importance of behavior theory in control system modeling of physical activity sensor data. In: Proceedings of the 36th Annual International Conference of the IEEE Engineering in Medicine and Biology Society. 2014 Presented at: 36th Annual International Conference of the IEEE Engineering in Medicine and Biology Society; Aug. 26-30, 2014; Chicago, IL, USA p. 6880-6883 URL: http://europepmc.org/abstract/MED/25571577 [doi: 10.1109/EMBC.2014.6945209]

99. Nahum-Shani I. Just-in-time adaptive interventions (JITAIs) in mobile health: key components and design principles for ongoing health behavior support. Ann Behav Med 2017 Dec 12;52(6):446-462. [doi: 10.1007/s12160-016-9830-8]

100. Ding X, Xu J, Wang H, Chen G, Herpreet T, Zhang Y. WalkMore: Promoting walking with just-in-time context-aware prompts. In: Proceedings of the IEEE Wireless Health (WH). 2016 Presented at: IEEE Wireless Health (WH); October 25-27, 2016; Bethesda, MD, USA. [doi: 10.1109/WH.2016.7764558]

101. Lin Y. Motivate: A Context-Aware Mobile Application for Physical Activity Promotion. Eindhoven: Technology University Eindhoven; Feb 01, 2013.

102. Minch RP. Privacy issues in location-aware mobile devices. In: Proceedings of the 37th Annual Hawaii International Conference on System Sciences, 2004. 2004 Jan 05 Presented at: 37th Annual Hawaii International Conference on System Sciences, 2004; January 5-8, 2004; Big Island, HI, USA. [doi: 10.1109/hicss.2004.1265320]

103. Satyanarayanan M. Pervasive computing: vision and challenges. IEEE Pers Commun 2020;8(4):10-17. [doi: $\underline{10.1109 / 98.943998]}$

104. Lee H, Kobsa A. Understanding user privacy in Internet of Things environments. In: Proceedings of the IEEE 3rd World Forum on Internet of Things (WF-IoT). 2016 Dec 12 Presented at: IEEE 3rd World Forum on Internet of Things (WF-IoT); Dec. 12-14, 2016; Reston, VA, USA. [doi: 10.1109/wf-iot.2016.7845392]

105. Clemes S, David BM, Zhao Y, Han X, Brown W. Validity of two self-report measures of sitting time. J Phys Act Health 2012 May;9(4):533-539. [doi: 10.1123/jpah.9.4.533] [Medline: 21946087] 
106. Gibbs B, Hergenroeder AL, Katzmarzyk PT, Lee IM, Jakicic JM. Definition, measurement, and health risks associated with sedentary behavior. Med Sci Sports Exerc 2015 Jun;47(6):1295-1300. [doi: 10.1249/MSS.0000000000000517] [Medline: 25222816]

107. Edwardson CL, Winkler EA, Bodicoat DH, Yates T, Davies MJ, Dunstan DW, et al. Considerations when using the activPAL monitor in field-based research with adult populations. J Sport Health Sci 2017 Jun;6(2):162-178 [FREE Full text] [doi: 10.1016/j.jshs.2016.02.002] [Medline: $\underline{30356601]}$

108. Henson J, Davies MJ, Bodicoat DH, Edwardson CL, Gill JM, Stensel DJ, et al. Breaking up prolonged sitting with standing or walking attenuates the postprandial metabolic response in postmenopausal women: a randomized acute study. Diabetes Care 2016 Jan;39(1):130-138. [doi: 10.2337/dc15-1240] [Medline: 26628415]

109. Buckley JP, Mellor DD, Morris M, Joseph F. Standing-based office work shows encouraging signs of attenuating post-prandial glycaemic excursion. Occup Environ Med 2014 Feb 02;71(2):109-111. [doi: 10.1136/oemed-2013-101823] [Medline: $\underline{24297826]}$

110. Klasnja P, Hekler EB, Shiffman S, Boruvka A, Almirall D, Tewari A, et al. Microrandomized trials: an experimental design for developing just-in-time adaptive interventions. Health Psychol 2015 Dec;34S(Suppl):1220-1228 [FREE Full text] [doi: 10.1037/hea0000305] [Medline: 26651463]

111. Cradock KA, ÓLaighin G, Finucane FM, Gainforth HL, Quinlan LR, Ginis KA. Behaviour change techniques targeting both diet and physical activity in type 2 diabetes: a systematic review and meta-analysis. Int J Behav Nutr Phys Act 2017 Feb 08;14(1):18 [ㅍREE Full text] [doi: 10.1186/s12966-016-0436-0] [Medline: 28178985]

\author{
Abbreviations \\ mHealth: mobile health \\ MVPA: moderate-to-vigorous physical activity \\ PA: physical activity \\ PRISMA: Preferred Reporting Items for Systematic Reviews and Meta-Analyses \\ PROSPERO: International Prospective Register of Systematic Reviews \\ RCT: randomized controlled trial \\ SB: sedentary behavior \\ SCT: social cognitive theory
}

Edited by R Kukafka; submitted 07.12.20; peer-reviewed by R Krukowski, F Tabei; comments to author 16.12.20; revised version
received 29.12.20; accepted 30.04.21; published 13.09.21
Please cite as:
Daryabeygi-Khotbehsara R, Shariful Islam SM, Dunstan D, McVicar J, Abdelrazek M, Maddison $R$
Smartphone-Based Interventions to Reduce Sedentary Behavior and Promote Physical Activity Using Integrated Dynamic Models:
Systematic Review
JMed Internet Res 2021;23(9):e26315
URL: https://www.jmir.org/2021/9/e26315
doi: $10.2196 / 26315$
PMID:

CReza Daryabeygi-Khotbehsara, Sheikh Mohammed Shariful Islam, David Dunstan, Jenna McVicar, Mohamed Abdelrazek, Ralph Maddison. Originally published in the Journal of Medical Internet Research (https://www.jmir.org), 13.09.2021. This is an open-access article distributed under the terms of the Creative Commons Attribution License (https://creativecommons.org/licenses/by/4.0/), which permits unrestricted use, distribution, and reproduction in any medium, provided the original work, first published in the Journal of Medical Internet Research, is properly cited. The complete bibliographic information, a link to the original publication on https://www.jmir.org/, as well as this copyright and license information must be included. 